Fall 1998

\title{
Neocolonialism, Anticommons Property, and Biopiracy in the (Not- so-Brave) New World Order of International Intellectual Property Protection
}

Keith Aoki

University of Oregon School of Law

Follow this and additional works at: https://www.repository.law.indiana.edu/ijgls

Part of the Intellectual Property Law Commons, and the International Law Commons

\section{Recommended Citation}

Aoki, Keith (1998) "Neocolonialism, Anticommons Property, and Biopiracy in the (Not-so-Brave) New World Order of International Intellectual Property Protection," Indiana Journal of Global Legal Studies: Vol. 6 : Iss. 1 , Article 2.

Available at: https://www.repository.law.indiana.edu/ijgls/vol6/iss1/2

This Symposium is brought to you for free and open access by the Law School Journals at Digital Repository @ Maurer Law. It has been accepted for inclusion in Indiana Journal of Global Legal Studies by an authorized editor of Digital Repository @ Maurer Law. For more information, please contact rvaughan@indiana.edu.

\section{$\Psi$}

JEROME HALL LAW LIBRARY

INDIANA UNIVERSITY

Maurer School of Law
Blooming ton 


\title{
Neocolonialism, Anticommons Property, and Biopiracy in the (Not-So-Brave) New World Order of International Intellectual Property Protection
}

\author{
KEITH AOKI*
}

\section{INTRODUCTION}

One of the biggest mistakes one can make when considering the globalization of intellectual property law is to assume away the increasingly contentious politics of the phenomenon. This is not to say that the emerging politics of international intellectual property law are simple, easy to understand, or unchanging - quite the contrary is true. However, we should resist the understandable tendency to reach for a quick, technocratic set of Procrustean tools that assume away the "messiness of the world" and make it seem that concepts such as "sovereignty" and "property" should be, are, or always have been, particularly stable constructs. Professor Fred Cate has brought together at the Roundtable a diverse group of scholars working from a wide range of political and ideological positions. He should be commended for avoiding the pitfalls of a "Jetson's Jurisprudence" type of gathering that sanguinely implies that the "future is so bright, we need to wear sunglasses" because of a quick techno fix.

In the not-so-brave new world order ${ }^{2}$ following the collapse of the Soviet Union in 1989, questions about the limits of the nation-state and the market are more important than ever. In particular, when considering developments, such

- Associate Professor, University of Oregon School of Law; B.F.A., 1976 Wayne State University; M.A., 1986, Hunter College; J.D., 1990, Harvard Law School; LL.M., 1993, University of Wisconsin School of Law. Thanks to Fred Cate for inviting me to participate in this symposium as well to James Boyle, Rosemary Coombe, Ruth Gana, and Carol Rose, whose work continues to educate, inspire and challenge me. Thanks also to David Kennedy and other participants at the Dighton Writer's Workshop, where I presented a draft.

1. James Boyle coined the term "Jetson's Jurisprudence" which refers to a "style of legal writing [that employs] a listing of technological marvels in the hope they will make a related set of legal rules alluringly futuristic by association." Shamans, SoFTwARE aND SPLEENS: LAW AND THE CONSTRUCTION OF THE INFORMATION SOCIETY at X (1996).

2. NOAM CHOMSKY, WORLD ORDERS OLD AND NEW (1994). 
as the spread of the World Wide Web, the jurisdictional scope of national regulatory regimes (whether specifically applicable to intellectual property per $\mathrm{se}^{3}$ or not, as is the case with laws regulating things like hate speech, pornography, obscenity, privacy, or encryption) is forced to the fore. However, the digital environment is not the only front on which questions about extraterritorial assertions of sovereignty are pressing. Indeed, one might look at the rise and spread of digital communications technologies as a smaller part of the dramatic global economic restructuring during the last half of the twentieth century that has been referred to as globalization. ${ }^{4}$

There are three large categories that may help us structure a discussion about the politics of international intellectual property protection. These categories consist of issues raised when asking questions about the following: (1) the political economy of intellectual property, considered both domestically and globally; (2) that which James Boyle has called "Logging the Cyberforest," basically, how are we to think about the intellectual "commons," or public domain; and (3) the legitimacy of various types of cultural (in the broadest sense) appropriation. I will briefly describe some of the issues in each of these three areas and suggest some tentative connections pointing in the direction of understanding the rapidly emerging politics of intellectual property law, international and otherwise.

3. For an excellent overview of the technological dilemmas facing contemporary U.S. copyright law and urging a return to its constitutionally-mandated ambit, see Fred H. Cate, The Technological Transformation of Copyright Law, 81 lowa L. REv. 1395 (1996); see also Jessica D. Litman, Copyright, Compromise and Legislative History, 72 CORNELL L. REV. 857 (1987) (examining some interpretive problems of the 1976 Copyright Act).

4. See, e.g., Peter Dicken, Global ShIFT: INDUSTRIal Change In A Turbulent World (1986) (providing a useful overview from the perspective of economic geography of the economic processes referred to as "globalization"); ROLAND ROBERTSON, GLOBALIZATION: SOCIAL THEORY AND GLOBALCULTURE (1992); GLOBAL CULTURE, NATIONALISM, GLOBALIZATIONAND MODERNITY 7 (Mike Featherstone ed., 1992) (special volume including articles from a range of theoretical perspectives on the significance of culture within the contemporary processes of global change); Paul Hirst \& Grahame Thompson, The Problem of 'Globalization': International Economic Relations, National Economic Management and the Formation of Trading Blocs, 21 ECON. \& SOC'Y 357 (1992); DAVID HARVEY, THE CONDITION OF POSTMODERNITY: AN ENQUIRY INTO THE ORIGINS OF CULTURAL CHANGE(1989); Bruce Robbins, Some Versions of U.S. Internationalism, 45 SOC. TEXT 97 (1995).

5. James Boyle coined this term during a presentation entitled "The Intellectual Property Grab" at the New Approaches to International Law "fin-de-NAIL" conference at Harvard Law School (May 1996). Cf. James Boyle, A Politics of Intellectual Property: Environmentalism for the Net?, 47 DUKE L.J. 87 (1997). 


\section{THE EMERGING POLITICAL ECONOMY OF INTERNATIONAL INTELLECTUAL PROPERTY LAW}

First, one should note that there is a deep contradiction between the definition of an "intellectual property right," that is, a state-backed monopoly handed out to individuals or firms, and the popular neoliberal vision that valorizes "privatization" and free market economics. ${ }^{6}$ Neoliberalism has three distinctive analytical characteristics that need to be on the table before discussing the international political economy of intellectual property. ' First, neoliberalism makes an ideological claim about a strict division between public and private. Second, neoliberalism entails a sort of "Forward into the Past" elevation of freedom of contract that is similar in many ways to the Lochner-era jurisprudence of the late nineteenth and early twentieth century United States. ${ }^{8}$ Third, and similarly, neoliberalism has a strong attachment to a type of conceptual formalism that tends to characterize actors, whether individual contracting parties or nations, as abstract and formally equal.

Central to the neoliberal vision is a strict split between the "public sphere" (the state) and the "private sphere" (the market), with the latter privileged and the former strictly cabined." This is an ideological claim analogous to a situation in which someone says, "It's not the money, it's the principle." However, more often than not, it is the money. Here, the conceptual importance

6. See generally David C. Korten, The Mythic Victory of Market Capitalism, in THE CASE AGAINST THE GLOBAL ECONOMY: AND FOR A TURN TOWARD THE LOCAL 183 (Jerry Mander \& Edward Goldsmith eds., 1996) [hereinafter THE CASE AGAINST THE GLOBAL ECONOMY]; WILLIAM GREIDER, ONE WORLD, READY OR Not: The Manic Logic of Global Capitalism (1997).

7. Cf. David Morris, Free Trade: The Great Destroyer, in ThECASE AgaINST THE Global Economy, supra note 6, at 218 (critiquing the politics and ideology of free trade); Tariq Banuri, Development and the Politics of Knowledge: A Critical Interpretation of the Social Role of Modernization Theories in the Development of the Third World, in DoMinating KNOWLEDge: DEVElOPMENT, CultuRE, AND RESISTANCE 29 (Frederique Apffel Marglin \& Stephen A. Marglin eds., 1990); David Slater, Contesting Occidental Visions of the Global: The Geopolitics of Theory and North-South Relations, MAS ALLA DEL DERECHO [BEYOND LAW: STORIES OF LAW AND SOCIAL CHANGE FROM LATIN AMERICA AND AROUND THE WORLD], December 1994, at 97; ARJUN APPADURAI, MODERNITY AT LARGE: Cultural DimENSIONS OF Globalization (1996).

8. Julie E. Cohen, Lochner in Cyberspace: The New Economic Orthodoxy of "Rights Management," 97 MiCh. L. REV. (forthcoming Nov. 1998); $c f$. RICHARD A. EPSTEN, TAKINGS: PRIVATE PROPERTY AND THE POWER OF EMINENT DOMAIN 279-82 (1985).

9. See Morton J. Horowitz, The History of the Public/Private Distinction, 130 U. PA. L. REV. 1423 (1982); Gerald E. Frug, The City as a Legal Concept, 93 HARv. L. REv. 1057, 1099-1105 (1980); Joseph William Singer, Legal Realism Now, 76 CAL. L. REV. 465, 477-95, 528-32 (1988) (book review); see also Richard Peet \& Michael Watts, Development Theory and Environment in an Age of Market Triumphalism, 69 ECON. GEOGRAPHY 227 (1993); see generally, AMERICAN LEGAL REALISM 98-129 (William W. Fisher et al. eds., 1993). 
of claiming a strict public and private split works to mask the proliferation and interpenetration of public and private as exemplified by institutions like nongovernmental organizations (NGOs) of all types. ${ }^{10}$ It is interesting that the "public" and "private" international institutions have also converged in the area of intellectual property law. For example, the "public" international institutions of Dumbarton Oaks, such as the United Nations, have intersected with the World Trade Organization (WTO), which developed from the postwar Bretton Woods "private" institutions, such as the International Monetary Fund (IMF), the World Bank, and the General Agreement on Tariffs and Trade (GATT). ${ }^{11}$ It is also ironic that this interpenetration is simultaneously obscured by assertions that "intellectual property rights are private rights."12

To the extent that neoliberalism undergirds the push toward "free trade" exemplified by multilateral agreements such as GATT, its successor-WTO, the North American Free Trade Agreement (NAFTA), and the formation of the European Union, there exists an irony first pointed out early in the twentieth century by U.S. legal realists such as Morris Cohen and Robert Hale. ${ }^{13}$ Cohen

10. Representative organizations include the Canadian-based Rural Advancement Foundation International (RAFI), the Women and Development Unit (WAND) in the Caribbean, Transafrica, and organizations referred to in Ibrahim F. I. Shihata, The World Bank and Non-Governmental Organizations, 25 CORNELL INT'L L.J. 623 (1992); and Enrique R. Carrasco, Law, Hierarchy, and Vulnerable Groups in Latin America: Towards a Communal Model of Development in a Neoliberal World, 30 STAN. J. INT'L L. 221 (1994); see also John Clark, Democratizing Development: The Role of Voluntary Organizations (1991); Peter J. Spiro, New Global Communities: Nongovernmental Organizations in International Decisionmaking Institutions, WASH. Q., Winter 1995, at 45; Brian H. Smith, An Agenda of Future Tasks for International and Indigenous NGOs: Views From the North, 15 WORLD DEV. 87 (Supp. 1987); Carolyn Stremlau, NGO Coordinating Bodies in Africa, Asia, and Latin America, 15 WORLD DEV. 213 (Supp. 1987); Yash Tandon, Foreign NGOs, Uses and Abuses: An African Perspective, IFDA DossIER, Apr.-June 1991, at 67, 70-72.

11. See generally David C. Korten, The Failure of Bretton Woods, in THE CASE AGAINST THE GLOBAL ECONOMY, supra note 6, at 20; Richard N. Gardner, The Bretton Woods-GATT System After Fifty Years: A Balance Sheet of Success and Failure, in THE BRETTON WOODS-GATT SYSTEM: RETROSPECT AND PROSPECT AFTER FIFTY YEARS 181 (Orin Kirshner ed., 1996); INTERNATIONAL MONETARY FUND \& WORLD BANK GROUP, FIFTY YEARS AFTER BRETTON WOODS: THE FUTURE OF THE IMF AND THE WORLD BANK (James M. Boughton \& K. Sarwar Lateef eds., 1995); MANAGING THE WORLDECONOMY: FIFTY YEARS AFTER Bretton Woods (Peter B. Kenen ed., 1994); John H. Jackson, THE World Trading SySteM: LAW and POLICY OF INTERNATIONAL ECONOMIC RELATIONS (1989); BEYOND BRETTON WOODS: ALTERNATIVES TO THE GLOBAL ECONOMIC ORDER (John Cavanagh et al. eds., 1994); 50 Years Is EnOUgh: THE CASE AGAINST THE WORLD BANK AND THE INTERNATIONAL MONETARY FUND (Kevin Danaher ed., 1994); PERPETUATING POVERTY: THE WORLd BANK, THE IMF, AND THE DEveloping WORLd (Doug Bandow \& Ian Vasquez eds., 1994).

12. Agreement on Trade-Related Aspects of Intellectual Property Rights, Including Trade in Counterfeit Goods of the General Agreement on Tariffs and Trade, December 15, 1993,33 I.L.M. 81 (1994)("Recognizing that intellectual property rights are private rights").

13. See Morris Cohen, Property and Sovereignty, 13 CoRNell L.Q. 8 (1927); Robert L. Hale, Bargaining, Duress, and Economic Liberty, 43 COLUM. L. REv. 603 (1943); Robert L. Hale, Coercion and 
pointed out that so-called "private property" rights of individuals and firms were more or less state-backed delegations of public sovereignty - the ability to "tax" future social output. ${ }^{14}$ Furthermore, Robert Hale wrote that the state's coercive force was similarly implicated in every "private" transaction in the market - even state noninterference with market transactions was a form of "public" intervention-by allowing and creating the legal rules of the game for private property owners to coerce one another in the "private" sphere, thereby implicating the state in underwriting "private" markets and their outcomes. ${ }^{15}$ If intellectual property may be fairly characterized as a jointly produced social product, ${ }^{16}$ then the state-underwritten rules determining allocation of benefits from production of that social product constitute a delegation of the sovereign's power to "tax" via licensing, or, conversely, fair uses.

In agreements such as the Trade-Related Aspects of Intellectual Property

Distribution in a Supposedly Non-Coercive State, 38 PoL. SCI. Q. 470 (1923); Robert L. Hale, Rate Making and the Revision of the Property Concept, 22 Colum. L. REv. 209 (1922); For a contemporary gloss on the continuing relevance of Robert Hale's work and Legal Realism in general see the chapter entitled "The Stakes of Law, or Hale and Foucault!" in Duncan Kennedy's book SEXY DRESSING, ETC.: ESSAYS ON THE POWER AND Politics OF CULTURAL IDENTITY 83-125 (1994).

14. See Cohen, supra note 13, at 12-13.

15. Hale, Coercion and Distribution in a Supposedly Non-Coercive State, supra note 13, at 471-73.

16. See KENNEDY, supra note 13, at 85-86:

The [legal] realists' coercion analysis contained a substantive insight as well, an insight into the role of legal rules. The state uses force to ensure obedience to the rules of the game of bargaining over a joint product. To the extent that these rules affect the outcome, forcing the parties to settle for $x$ rather than $y$ percent of the joint product, the state is implicated in the outcome. It is an author of the distribution even though that distribution appears to be determined solely by the 'voluntary' agreement of the parties.

It is not a stretch to conceive of "intellectual property" as a joint product, consisting of differing proportions of preexisting works and ideas.

Furthermore, in the intellectual property area, the state is expressly implicated in conferring (or modifying) rights. This becomes clear when one realizes the "flip-ability" value in the area of fair use. For example, is the fair use doctrine a subsidy flowing to the public of users or consumers of copyrighted works? Or is a strong vision of copyright a subsidy flowing to authors from the public of potential users or consumers of works? It is far from clear that there is any determinate answer to the "efficiency" of either outcome. For a penetrating and useful analysis of the impossibility of establishing any neutral, prepolitical default from which to assess value, see Duncan Kennedy \& Frank I. Michelman, Are Property and Contract Efficient?, 8 HoFSTRA L. REv. 711 (1980). See also Lloyd L. Weinreb, Copyright for Functional Expression, 111 HaRv. L. REv. 1149, $1239-40$ (1998):

Even if allocative efficiency alone is considered, the desirable nature and extent of a copyright regime are uncertain. Why, after all, should the author or publisher of a work own the copyright rather than just the copy itself? . . Copyright has the effect of 'privatizing' and thereby bringing into the market goods that would otherwise be free to all. The longstanding convention that authors have a copyright in their works deflects attention from the fact that copyright is itself an intervention in the market, rather than as is so often made to appear, the 'natural' way of things. 
Rights (TRIPS) component of GATT and the WTO, there are serious questions as to what nations, regions, and classes of persons benefit from "free trade," whether it be in scientific textbooks, bestsellers, bytes, germ plasm, or CDs. ${ }^{17}$ On issues as far-ranging as the impact on scientific research of restrictive database protection laws ${ }^{18}$ to the impact on democratic dialogic participation, questions about the international political economy of intellectual property are becoming harder to avoid. ${ }^{19}$ In particular, as between the developed nations of the North and the less developed countries of the South ${ }^{20}$ increasing numbers of scholars have been questioning whether the flow of benefits of international intellectual property protection, which are part of the whole "free trade"

17. "Copyright industries [of Western Europe and North America] are not economically marginal-25 billion dollars in 1985 in Britain, 2.9 per cent of the Gross National Product (GNP), greater than car manufacturing. ... [T] he United States in 1990 ... estimat[ed] that copyright industries contribute 5.8 per cent of the U.S. GNP, employing almost 5 per cent of the U.S. workforce." Urvashi Butalia, The Issues at Stake: An Indian Perspective on Copyright, in COPYRIGHT AND DEVELOPMENT: INEQUALITY IN THE INFORMATION AGE 49, 52 (Philip G. Altbach ed., 1995) [hereinafter COPYRIGHT AND DEVELOPMENT]; Alan S. Gutterman, The North-South Debate Regarding the Protection of Intellectual Property Rights, 28 WAKE FOREST L. REV. 89 (1993).

18. See the Database Investment and Intellectual Property Antipiracy Act of 1996, H.R. 3531, 104 Cong. $\$ 2$ (1996); see also Committee of Experts on a Possible Protocol to the Berne Convention, Proposal of the United States of America on Sui Generis Protection of Databases, Geneva, May 22-24, 1996, WIPO Doc. BCP/CE/VII/2-INR/CE/VI/2 (May 24, 1996) (rejected by WIPO in December 1996); World Intellectual Property Organization, Draft WIPO Copyright Treaty, December 20, 1996, WIPO Doc. No. CRNR/DC/89 (December 20, 1996) [hereinafter Draft WIPO Copyright Treaty]; Pamela Samuelson, Big Media Beaten Back, WIRED, March 1997, at 61; Denise Caruso, Global Debate Over Treaties on Copyright, N.Y. TiMES, Dec. 16, 1996, at D1 (describing the bill that incorporated the White Paper's proposals of "failed legislation").

19. See Boyle, supra note 1; ANNE Wells Branscomb, Who OWNS INFORMation? From Privacy TO PUbLIC ACCESS (1994); Rosemary J. Coombe, Objects of Property and Subjects of Politics: Intellectual Property Laws and Democratic Dialogue, 69 TEX. L. REV. 1853 (1991); Niva Elkin-Koren, Copyright Law and Social Diaglogue on the Information Superhighwoy: The Case Against Copyright Liability of Bulletin Board Operators, 13 CARDOzo ARTS \& ENT. L.J. 345 (1995); Niva Elkin-Koren, Cyberlaw and Social Change: A Democratic Approach to Copyright Law in Cyberspace, 14 CARDozo ARTS \& ENT. L.J. 215 (1996); Neil Weinstock Netanel, Copyright and a Democratic Civil Society, 106 YALE L. J. 283 (1996); Keith Aoki, (Intellectual) Property and Sovereignty: Notes Toward a Cultural Geography of Authorship, 48 Stan. L. Rev. 1293 (1996); Neil Weinstock Netanel, Asserting Copyright's Democratic Principles in the Global Area, 51 VAND. L. REV. 217 (1998).

20. See Andrew Pollack, A Cyberspace Front in a Multicultural War, N.Y. TIMES, Aug. 7, 1996, at D1, featuring a map of what regions of the world are "wired" provided by the Internet Society, in which most of SubSaharan Africa, with the exception of South Africa, is unconnected to the Internet. The map's title reads "Connected, but Not Communicating" and its captions state:

North and South America both use Latin alphabets, making computer communication between them relatively easy. ... There are few computer networks in Africa, and the large number of dialects, languages, and alphabets makes electronic communication difficult. ... Most of Europe can communicate with Latin script. China and other Asian countries require more complicated character sets than the Internet allows.

Id. 
package, may be skewed to the advantage of the economies, cultures, and nations of the North. ${ }^{21}$ To the extent that the countries of the North have developed bifurcated economies with large wealth gaps between rich and poor, the concerns of the nations of the South fold into pockets of Third World-like immiseration within the First World..$^{22}$

21. See Vandana Shiva, BIopiracy: The Plunder of Nature and KNowledge (1996) [hereinafter Biopiracy]; Vandana Shiva, Monocultures of the Mind: Perspective on Biodiversity and BIOTECHNOLOGY (1993); COPYRIGHT AND DEVELOPMENT, sLPra note 17; BOYLE, sLPra note 1; INTELLECTUAL Property Rights and INDigenous PEOPLeS: A SourcebooK (Tom Greaves ed., 1994); Jack R. Kloppenberg, JR., First the Seed: The Political Economy of Plant Biotechnology (1988); Ruth L. Gana, The Myth of Development, The Progress of Rights: Human Rights to Intellectual Property and Development, 18 LAW \& POL'Y 315 (1996) [hereinafter Gana, The Myth of Development]; Ruth L. Gana, Has Creativity Died in the Third World? Some Implications of the Internationalization of Intellectual Property, 24 DENV. J. INT'L L. \& POL'Y 109 (1995) [hereinafter Has Creativity Died in the Third World?]; Darrell Addison Posey, Intellectual Property Rights: What is the Position of Ethnobiology?, $10 \mathrm{~J}$. ETHNOBIOLOGY 93 (1990); Darrell Posey, Intellectual Property Rights and Just Compensation for Indigenous Knowledge, ANTHROPOLOGY TODAY, Aug. 1990, at 13; see also Judith C. Chin \& Gene A. Grossman, Intellectual Property Rights and North-South Trade 10506 (National Bureau of Economic Research Working Paper No. 1040, 1990); Carlos Alberto Primo Braga, The Economics of Intellectual Property Rights and the GATT: $A$ View From the South, 22 VAND. J. TRANSNAT'L L. 243, 254 (1989); J. H. Reichman, Intellectual Property in International Trade: Opportunities and Risks of a GATT Connection, 22 VAND. J. TRANSNAT'L L. 747, 861-63 (1989); Ricardo Grinspun \& Robert Kreklewich, Consolidating Neo-Liberal Reforms: Free Trade as a Conditioning Framework, (May 27-29, 1994) (unpublished paper presented to the International Conference on Economic Integration and Public Policy: NAFTA, the European Union and Beyond, York University, Toronto. "The new trading arrangements effectively remove many economic and social policy objectives from democratic consideration. These policy changes are directed to inhibit governments from engaging in interventionist policies in particular in the area of export promotion and import protection.")

22. Saskia Sassen, On Concentration and Centrality in the Global City, in WORLD CITIES N A WORLD SySTEM 63, 71 (Paul Knox \& Peter J. Taylor eds., 1995):

[W]e are ... [s] eeing the formation of a transterritorial 'centre' constituted via digital highways and intense economic transactions. ... New Yòrk, London, and Tokyo could be seen as constituting such a transterritorial terrain of centrality.... And at the limit we may see terrains of centrality that are disembodied, that lack any territorial correlate, that are in the electronically generated space we call cyberspace. ... One question here is whether the type of spatial organization characterized by dense strategic nodes spread over the broader region does or does not constitute a new form of organizing the territory of the 'centre', rather than, as in the more conventional view, an instance of suburbanization or geographic dispersal.

See also SASKIA SASSEN, THE GLOBAL CTTY: NEW YORK, LONDON, TOKYO (1991); HERBERT I. SCHLLER, INFORMATION INEQUALITY: THE DEEPENING SOCLAL CRISIS N AMERICA XVi (1996):

[T] he information crisis-denial of access and debased messages and images-deepens social inequality and intensif[ies] the general social crisis. . . [T] [Te media informational sector ... [h]as become a major site of employment and income (domestic and intemational), and also provides an increasingly integrated symbolic environment from which the nation derives its ideas, values, expectations. ... The character and quality of message and image flow, therefore, is a crucial terrain of contestation in the time ahead. 
In particular, disparities between North and South ${ }^{23}$ are most pronounced as to the question of "free trade" and its relationship with the idea of "development." The question facing the postwar architects of the world economic order was, Now that colonialization has ended, how do we move on $?^{25}$ In the 1960s, development of the Third World was seen as crucial, and the means whereby development would occur was via technological transfers. ${ }^{26}$

23. Anthony D. Taibi, Racial Justice in the Age of the Global Economy: Community Empowerment and Global Strategy, 44 DUKE L.J. 928, 975 n.118 (1995):

[T] he disparity between the richest countries in the world (bearing in mind that at least half of our people are not so rich) and the poorest in terms of income and access to basic resources (safe drinking water, sufficient caloric intake, medical attention and sanitation, education, and so on) is about 150 to $1 .$. . The North with about one-fourth of the world's population, consumes $70 \%$ of the world's energy, $75 \%$ of its metals, $85 \%$ of its wood and $60 \%$ of its food.

(citing Human Development Report 1992, U. N. Development Programme, at 34 (1992)).

24. See generally Report of the Working Group of Governmental Experts on the Right to Development, U.N. Commission on Human Rights, U.N. Doc. E/CN. 4/1489 (1982); U.N. Declaration on the Right to Development, G.A. Res. 41/128, U.N. GAOR, 41 st Sess., Supp. No. 53, at 186, U.N. Doc. A/41/53 (1986); Christopher ChASE-DUNN, Global Formation: STRUCTURES OF THE WORLD-ECONOMY (1989); ARTURO EsCobar, ENCOUNTERING DEVElopMENT: THE MAKING AND UNMAKING OF THE THIRD WORLD (1995);

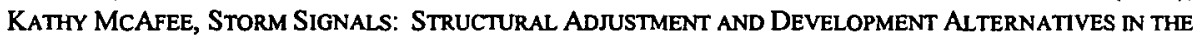
CARIBbean (1991); Russell Lawrence Barsh, The Right to Development as a Human Right: Results of a Global Consultation, 13 HUM. RTs. Q. 322 (1991); Enrique R. Carrasco \& M. Ayhan Kose, Income Distribution and the Bretton Woods Institutions: Promoting an Enabling Environment for Social Development, 6 Transnat'L L. \& Contemp. Probs. 1 (1996); Arturo Escobar, Reflections on 'Development': Grassroots Approaches and Alternative Politics in the Third World, 24 Futures 411 (1992); The Myth of Development, supra note 21; Elizabeth M. Iglesias, Auman Rights in International Economic Law: Locating the Latinas/os in the Linkage Debates, 28 U. MIAMI INTER-AM. L. REV. 361 (19961997); James C. N. Paul, The Human Right to Development: Its Meaning \& Importance, 25 J. MARSHALL L. REv. 235 (1992); Richard Warren Perry, Rethinking the Right to Development: After the Critique of Development, After the Critique of Rights, 18 LAW \& POL'Y 225 (1996); L. Amede Obiora, Beyond the Rhetoric of a Right to Development, 18 LAW \& POL'Y 355 (1996).

25. See Elliot M. Burg, Law and Development: A Review of the Literature \& A Critique of "Scholars in Self-Estrangement," 25 AM. J. CoMP. L. 492 (1977); John Henry Merryman, Comparative Law and Social Change: On the Origins, Style, Decline \& Revival of the Law and Development Movement, 25 AM. J. COMP. L. 457 (1977); Robert Seidman, Law and Development: A General Model, 6 LAW \& Soc'Y REv. 311 (1972); David M. Trubek \& Marc Galanter, Scholars in Self-Estrangement: Some Reflections on the Crisis in Law and Development Studies in the United States, 1974 WIS. L. REV. 1062.

26. See Perry, supra note 24, at 236-37:

To understand the post-War development project, we must situate it historically alongside the Marshall Plan, its "foreign aid" cousin, whose goal was to counter the Soviet Union's menace to the United States' primacy in Europe through strategic infusion of U.S. capital for the redevelopment of Europe's economic infrastructure. Indeed, the development framework for North-South geopolitical relations was no less integral to the new post-World War II world order than was the East-West strategic confrontation that we know as the Cold War. ... Arturo Escobar ... argues that, from the late 1940's, ... paleo-colonial notions of development underwent a paradigm shift as the Truman-era development agenda engendered its logical counterpart, a new 
An explicit assumption of development theories of this period was that the United States and Western European nations achieved a high level of development because of their intellectual property systems that fostered innovation; therefore, what worked for the West should work for the rest. ${ }^{27}$ One main push during this period was for the countries of the developing world to adopt intellectual property regimes based on transplanted U.S. and European models; technological advancement would take care of itself. ${ }^{28}$ Unfortunately, development did not occur on this unilinear model, and during the 1970s, development of the sort that aimed to make the Third World look like the First World received increasing criticisms as uneven development persisted. ${ }^{29}$ During the 1980s and 1990s, structural adjustment policies advanced by the IMF and

conceptualization of underdevelopment. . . . The Truman-era development agenda would set the conceptual framework, the ground-rules, according to which the First and Second Worlds would contend for hegemony over the newly christened Third.

27. Id. at 237-38:

The dualist model of development/modernization theory depicts the "problem" of underdevelopment as a matter to be remedied by a benign process through which the "modern world", together with the "advanced" ("Westernized," "modernized,") elite sectors of "backward" societies collaborate to "overcome" those societies' recalcitrant "traditionalism" that stood as a barrier to their progress. One implication of this conceptual framing was that persevering resistance to Western hegemony - in either its classically colonialist or neocolonialist forms - now could be marginalized not simply as anti-Western, but also as anti-modern, as a stubborn obstacle in the one-way street of progress, as anti-development.

See also Gana, The Myth of Development, supra note 21, at 349 n.39.

The theory that development is unilinear is an outgrowth of Darwinian thought which holds that progress is inevitable. According to this theory, poor countries of the world are simply replicas of developed countries at earlier stages in the[ir] development. With time, developing countries would go through their own industrial revolution and eventually achieve a level of development comparable to developed countries.

Margaret Chon, Postmodern "Progress": Reconsidering the Copyright and Patent Power, 43 DEPAUL L. REV. 97 (1993).

28. Gana, The Myth of Development, supra note 21 , at 346 n.24:

The debate about the role of intellectual property is usually framed around the question of whether protection for intellectual property rights is a prerequisite for development. However, this question is not helpful unless the fundamental issue of differences in values that underlie political, social, and legal institutions in countries is factored into the models of protection for intellectual property.

29. See, for example, the work of Dependency theorists who critiqued the unilinear model of development, arguing that over rapid industrialization led to underdevelopment, ANDRE GUNDER FRANK, CAPTTAUSM AND UNDERDEVELOPMENT IN LATIN AMERICA: HISTORICAL STUDIES OFCHIILAND BRAZIL (1967); KEITH GRIFFIN, UNDERDEVELOPMENT IN SPANISH AMERICA (1969); FRANCES STEWART, TECHNOLOGY AND UNDERDEVELOPMENT (1977); IMMANUEL. WALIERSTEN, THE MODERN WORLD-SYSTEM (1974). But see ERNESTO LACLAU, POLTICS AND IDEOLOGY IN MARXIST TMEORY: CAPITALISM, FASCISM, POPULISM (1977); MARGARET C. SNYDER \& MARY TADESSE, AFRICAN WOMEN AND DEVELOPMENT: A HISTORY: THE STORY OF THE AFRICAN TRAINING AND RESEARCH CENTER FOR WOMEN OF THE UNTIED NATIONS ECONOMIC COMMISSION FOR AFRICA (1995). 
the World Bank tended to encourage privatized development. ${ }^{30}$

By the early 1990s, with the enactment of TRIPS, Third World countries might be thought of as being coerced into joining GATT, which literally said to Third World countries: If you want to export your goods, agricultural and otherwise, you must protect the intellectual properties of other nations. Thus, the cotton that passes out of Malaysia at one dollar per pound returns as a $t-$ shirt bearing the trademarked image of Mickey Mouse or Bart Simpson selling for twenty-five dollars. ${ }^{31}$ Under the ideological banner of "free trade," the intellectual property regimes of the developed nations were given expanded reach - in other words, rules that purportedly were meant to encourage and protect creative expression and scientific innovation were now put in place, giving owners the legal means to reach extraterritorially into Third World countries to prevent unauthorized use. ${ }^{32}$ TRIPS also places important constraints on the sovereignty of nations of the developing world to implement innovation schemes based on local and regional considerations, factors which may differ drastically from country to country and industry to industry. Ruth Gana writes:

Given the history of the international intellectual property system, the notion that either the pre- or post-TRIPS multilateral system is based upon consensus is still a myth as

30. SO YEARS IS ENOUGH: THE CASE AGANST THE WORLD BANK AND THE INTERNATIONAL MONETARY FUND, supra note 11; PERPETUATING POVERTY: THE WORLD BANK, THE IMF, AND THE DEVELOPING WORLD, supra note 11; Victor L. Urquidi, Reconstruction vs. Development: The IMF and the World Bank, in THE BRETTON WOODS-GATT SYSTEM: RETROSPECT AND PROSPECT AFTER FIFTY YEARS 30 (Orin Kirshner ed., 1996).

31. Keith Aoki, The Stakes of Intellectual Property Law, in THE Polmics of LAw: A Progressive CrITIQUE, 259 (David Kairys ed., 3d ed. 1998). See also Aoki, supra note 19; Rosemary J. Coombe, The Cultural Life of Things: Anthropological Approaches to Law and Society in the Conditions of Globalization, 10 AM. U. J. INT'L. L. \& POL'Y 791 (1995).

32. Gana, The Myth of Development, supra note 21. See also Joel R. Reidenberg, Governing Networks and Rule-Making in Cyberspace, in BORDERS INCYBERSPACE 84 (Brian Kahin \& Charles Nesson eds., 1996); Curtis A. Bradley, Territorial Intellectual Property Rights in an Age of Globalism, 37 VA. J. INT'L L. 505 (1997); Dan L. Burk, Federalism in Cyberspace, 28 CoNN. L. Rev. 1095 (1996); David R. Johnson \& David Post, Law and Borders: The Rise of Law in Cyberspace, 48 STAN. L. REV. 1367 (1996). See generally RESTATEMENT(THIRD) OF THE FOREIGN RELATIONS LAW OF THE U.S. § 402 (1987) (a state's "jurisdiction to prescribe" may be exercised with respect to "certain conduct outside its territory by persons not its nationals that is directed against the security of the state or against a limited class of other state interests."); Larry Kramer, Vestiges of Beale: Extraterritorial Application of American Law, 1991 SUP. CT. REV. 179, 184 ("the world in which a presumption against extraterritoriality made sense is gone."); Note, Constructing the State Extraterritorially: Jurisdictional Discourse, the National Interest and Transnational Norms, 103 HARV. L. REV. 1273 (1990). 
far as developing countries are concerned. Those countries that will feel the brunt of its provisions include both the African countries that remain on the periphery of the international market and the emerging economies in Asia whose markets are attractive to foreign investors from the developed countries.... [T] he TRIPS Agreement accomplishes, through the potential threat of economic ostracism, what could not be accomplished through negotiations independent of the international economic framework. . . Copyright and patent laws will continue to extract exorbitant costs from developing countries in exchange for access to literary works, computer programs or other technology. ... [G]iven the values reflected in the current intellectual property system, values which are deemed "universal" yet are clearly not, there is no assurance that the current framework will benefit developing countries in any significant way. ${ }^{33}$

With regard to the long-term effects of growing disparities between the developed world and the developing world on questions of technology transfer, Jerome Reichman has been prescient. Professor Reichman asks us to consider whether we are in control of our institutions or whether they are in control of us. ${ }^{34}$ By asking us to take North and South distributional consequences of intellectual property regimes seriously, Reichman asks us to consider the long-

33. Gana, The Myth of Development, supra note 21, at 334-35. See Ruth L. Gana, Prospects for Developing Countries under the TRIPS Agreement, 29 VAND. J. TRANSNAT'L L. 735 (1996); See also Marci A. Hamilton, The TRIPS Agreement: Imperialistic, Outdated and Overprotective, 29 VAND. J. TRANSNAT'L L. 613 (1996); Samuel A. Oddi, The International Patent System and Third World Development: Reality or Myth?, 1997 DUKE L.J. 831; Samuel A. Oddi, TRIPS - Natural Rights and a "Polite Form of Economic Imperialism," 28 VAND. J. TRANSNAT'L L. 415 (1996); Sam Ricketson, The Future of the Traditional Intellectual Property Conventions in the Brave New World of Trade-Related Intellectual Property Rights, 26 INT'L REV. INDUS. PROP. \& COPYRIGHT L. 872 (1995).

34. See J. H. Reichman, Charting the Collapse of the Patent-Copyright Dichotomy: Premises for a Restructured International Intellectual Property System, 13 CARDOzo ARTS \& ENT. L.J. 475 (1995); J. H. Reichman, Compliance With the TRIPS Agreement: Introduction to a Scholarly Debate, 29 VAND. J. TRANSNAT'L L. 363 (1996); J. H. Reichman, Enforcing the Enforcement Procedures of the TRIPS Agreement, 37 VA. J. INT'L L. 335 (1997); J. H. Reichman, From Free Traders to Fair Followers: Global Competition Under the TRIPS Agreement, 29 N.Y.U. J. INT'L L. \& POL. 11 (1997) [hereinafter Fair Followers]; see also J. H. Reichman, The TRIPS Component of the GATT's Uruguay Round: Competitive Prospects for Intellectual Property Owners in an Integrated World Market, 4 FORDHAM INTELL. PROP. MEDIA \& ENT. L.J. 171 (1993); J. H. Reichman, Universal Minimum Standards of Intellectual Property Protection under the TRIPS Component of the WTO Agreement, 29 INT'L LAW. 345 (1995) [hereinafter Universal Minimum Standards]. 
term effects of international intellectual property regimes that are now being put in place. Importantly, he recharacterizes the stakes of intellectual property protection as involving a struggle between clashing visions. On one hand, Reichman sees the nations and firms of the developed world promoting anticompetitive, maximalist policies under the ideological banner of "free (or fair) trade." ${ }^{35}$ On the other hand, the interests of the developing and least developed nations of the Third World may be advanced by either promoting procompetitive intellectual property strategies on the national or regional level, or what Reichman refers to as "fair following," involving "legitimate rights of local firms to reverse-engineer unpatented foreign technologies by honest means." ${ }^{36}$ With an eye toward long-term stabilization and relative equalization of the field of competition among the nations along the spectrum from North to South, developed to developing to least developing nations regarding economic relations, Reichman urges us to look critically upon the:

[P]rotectionist appetites of . . powerful industrial combinations that have successfully captured the legislative and administrative exponents of trade and intellectual property policies ... [and] where the interests of both consumers and small or medium-sized innovators are held hostage to the political influence of oligopolistic combinations that use intellectual property rights to expand market power. ${ }^{37}$

A specific example of this overreaching is the proposed (but rejected, for now at least) World Intellectual Property Organization (WIPO) Database Protection Treaty of $1996 .^{38}$ The economically formidable U.S. copyright and information industries recently lobbied Congress, the Commerce Department, international bodies such as WIPO (a subagency of the United Nations), and the

35. On the free trade-fair trade distinction, see generally Robert Howse \& Michael J. Trebilcock, The Fair Trade-Free Trade Debate: Trade, Labor and the Environment, 16 INT'L REV. L. \& EcoN. 61 (1996). In some ways, the arguments that undergird both the free trade and the fair trade positions in terms of upwardly harmonizing the international trade framework carry less persuasive power in the intellectual property area than in the environmental and labor rights area.

36. Fair Followers, supra note 34, at 92.

37. Id. at 17,25 .

38. Pamela Samuelson, The U.S. Digital Agenda at WIPO, 37 VA. J. INT'L L. 369 (1997). See also Basic Proposal on the Substantive Provisions of the Treaty on Intellectual Property in Respect of Databases to be Considered by the Diplomatic Conference, WIPO Doc. CR/NR/DC6 (Aug. 6, 1996); J.H. Reichman \& Pamela Samuelson, Intellectual Property Rights in Data?, 50 VAND. L. REV. 51 (1997). 
WTO to expand statutorily the content of both national and international protections for intellectual property. When WIPO met in Geneva in December 1996, the copyright, media, and information industry representatives behind the Commerce Department's White Paper of 1995 sought to implement globally five problematic protections of otherwise uncopyrightable information within databases ${ }^{39}$ advocated in the failed White Paper. ${ }^{40}$ Because of vocal protests from the international scientific and legal communities, who viewed the proposed Treaty as potentially disastrous for scientific research, the proposed Database Protection Treaty was rejected, and the White Paper-like proposals were taken under consideration for further discussion by WIPO. ${ }^{41}$ What is notable is that when the U.S. copyright and information industries could not get what they wanted on the domestic level, they sought to make a supranational end run, a tactic which has had some prior success with the TRIPS component

39. The 5 significant changes in domestic U.S. Copyright law that the failed 1995 White Paper advocated (which were advocated to WIPO in December 1996) were: (1) subjecting transitory or temporary copies in a computer Random Access Memory to the copyright owner's exclusive right to authorize reproductions thereby making RAM copies into infringing copies; (2) treating digital transmissions of copyrighted works as distributions to the public, thereby subjecting Internet Service Providers to a strict liability contributory infringement scheme; (3) imposing criminal sanctions as the penalty for tampering with copy-protection or management of digital texts; (4) curtailing the ability of states to make exceptions or limits on the exclusive rights of copyright owners, thereby modifying the "fair use" defense by instituting a problematic commercial and noncommercial use distinction and limiting first sale privileges; and (5) allowing copyright owners to challenge the manufacture and sale of technology or services that could circumvent copy-management or protection technology. In addition, the United States wanted WIPO to create a sui generis legal protection for the contents of databases. On the December 1996 WIPO discussions, see Peter H. Lewis, 160 Nations Meet to Weigh Revision of Copyright Law, N.Y. TumES, Dec. 2, 1986, at Al. See also James Love, Archive of WIPO Database Protection Materials (visited Sept. 22, 1998)<http://www.essential.org/listproc/info-policynotes $>$ (assembled by James Love of Taxpayer Assets Project and Consumer Project on Technology); Samuelson, supra note 38 , at $372-73$.

40. See Basic Proposal on the Substantive Provisions of the Treaty on Intellectual Property in Respect of Databases to be Considered by the Diplomatic Conference, WIPO Doc. CR/NR/DC6, art. 10 (August 30, 1996); Basic Proposal on the Substantive Provisions of the Treaty on Certain Questions Concerning the Protection of Literary and Artistic Works to be Considered by the Diplomatic Conference on Certain Copyright and Neighboring Rights Questions, WIPO Doc. CR/NR/DC4, art. 7(1), 13, 14 (August 30, 1996). See generally Samuelson, supra note 38.

41. See Draft WIPO Copyright Treaty, supra note 18. See also Samuelson, supra note 18; Caruso, supra note 18 (describing the bill that incorporated the White Paper's proposais as "failed legislation"). 


\section{of GATT. ${ }^{42}$}

Moving away from concerns about corporate ethnobotanists rifling through the shaman's bag in search of pharmaceutical miracles or designing legal protections for elections swirling globally in cyberspace, consider the printed book, a more quotidian item from the Age of Gutenberg, ${ }^{43}$ and how maximalist visions of internationalized copyright may negatively affect the educational and research capacity of nations in sub-Saharan Africa, Asia, or Latin America. ${ }^{44}$ During the nineteenth century, the United States was considered to be the

42. See Final Act Embodying the Results of the Unuguay Round of Multilateral Trade Negotiations, Legal Instruments Embodying the Results of the Uruguay Round of Mulitilateral Trade Negotians Done at Marrakesh on April 15, 1994, vol. 1; Annex 1C Agreement on Trade-Related Aspects of Intellectual Property Rights, Legal Instruments Embodying the Results of the Uruguay Round of Multilateral Trade Negotiations Done at Marrakesh on April 15, 1994, vol. 31, 33 I.L.M. 81 (1994). For the U.S. ratification of the TRIPS component of the WTO Agreements, see Uruguay Round Agreements Act, Pub. L. No. 103-465, $\S \S 101-103,108$ Stat. 4809 (1994). See also Universal Minimum Standards, supra note 34; Has Creativity Died in the Third World?, supra note 21.

43. See Philip G. Altbach, The Subtle Inequalities of Copyright, in COPYRIGHT AND DEVELOPMENT, supra note 17, at 1, 2, 5:

There is, in reality, a difference between a Mickey Mouse Watch, a Hollywood film, or even a computer software program, on the one hand, and a scientific treatise, on the other. Textbooks, technical reports, and research volumes are subject to the same copyright regulations as a novel by James Clavell. Those who control the distribution of knowledge treat all intellectual property equally - and are perfectly happy to deny access to anyone who cannot pay. . . . [1]t is important to realize that the international knowledge system is highly unequal, and it can be argued that those who are in control of the system-and specifically copyright arrangements-have a special responsibility to assist in the intellectual and educational development of the Third World. There is a kind of OPEC of knowledge in which a few rich nations and a small number of multinational publishers have a great deal of control over how and where books are published, the prices of printed materials, and the nature of international exchange of knowledge.

44. HenryM. Chakava, International Copyright and Africa: An Unequal Exchange, in COPYRIGHT AND DEVELOPMENT, supra note 17 , at 18 :

One can only assume that African countries have chosen to sign [onto the Berne Convention] because they believe this will facilitate the flow of knowledge from the North to their own countries... [T] he reality of the situation is that these rights holders [in the North] do not appear keen to extend printing licenses to African publishers. Instead they are using copyright as a weapon to maintain the dependency relations that currently exit. The African signatories have arrogated themselves the role of collecting copyright fees from their own people and remitting these to the owners in the North. This has serious repercussions for the cost of education, and for the future of the education industries in Africa. When Africa finally [achieves] the necessary economic, production and distribution infrastructures ... to permit proper commercial publishing to emerge . . . [Africa] will replace Asia as the battleground for piracy and other copyright infringement battles presently raging in the rest of the world. 
"Barbary Coast" of intellectual property. ${ }^{45}$ The United Nations Educational, Social \& Cultural Organization (UNESCO) reports that in 1993, while "Africa ha[d] $12 \%$ of the world's population, it produc[ed] only $1.2 \%$ of its books, and that this percentage is declining.... [Furthermore, Africa] controls only about $0.4 \%$ of the world's intellectual property." 46 By comparison, North America, which has roughly five percent of the world's population, produces thirteen percent of the world's books. Similarly, papers, journals, magazines, and " $80 \%$ of the world's knowledge industries are based in the North [where their output] is copyrighted." be able to enact local copyright laws that allow for compulsory licensing, expanding and strengthening rules regarding exemptions for education and research purposes, simplifying copyright assignment clauses, and working toward a multilateral reduction in copyright term duration. ${ }^{48}$ Admittedly, the tenor of the U.S. copyright industry's interpretation of TRIPS runs counter to these sorts of proposals, but at the very least, one should consider the importance of books and journals, particularly educational and scientific texts and in terms of generating local innovation, to the developing and least developed countries. Philip Altbach writes:

Copyright, after all, is a moral and ideological concept as well as a legal and economic one. There is no recognition that the

45. Altbach, supra note 43 , at 8 :

One of the most egregious violators of copyright in the nineteenth century was the United States, which felt, probably incorrectly, that it could build up its domestic publishing industry most effectively by freely reprinting works from abroad while protecting the rights of domestic authors. Once American publishing was well developed, the United States became a defender of copyright. Until the 1960s, the Soviet Union had a similar perspective-international copyright was violated as the country used knowledge from abroad for its own purposes. China had a similar perspective up to the 1990 s and has only recently joined the international copyright system. Nations must see copyright as in their best national interest before they become fully supportive of it.

See also Aubert J. ClaRK, THE MOVEMENT for INTERNATIONAL COPYRIGHT IN NINETEENTH CENTURY AMERICA (1960).

46. Chakava, supra note 44 , at $13,17,19$.

47. Id. at 17 .

48. See generally id:; Gana, The Myth of Development, supra note 21; Amadio A. Arboleda, Distribution: The Neglected Link in the Publishing Chain, in PUBLISHING IN THE THIRD WORLD: KNOWLEDGE AND DEVELOPMENT 42, 44 (Philip G. Altbach ed., 1985) ("Even meeting the basic needs for achieving mass distribution, i.e., adequate book manufacturing equipment, distribution equipment, display equipment, a distribution system and plan (including transportation), necessary capital, an adequate editorial and production staff, and tax relief, is beyond the capabilities of publishers in most developing countries."). 
legacy of colonialism and the power of multinationals has, to a significant extent, created the current highly unequal world knowledge system. It is, of course, much easier for the "haves" to cling to the economic and legal system that has given them a virtual monopoly over the world's knowledge products than to recognize that we live in an interdependent world and that the Third World desperately needs access to knowledge and technology.... [These needs] are not limited to the poor countries of the developing world. For example, Moscow's famed Lenin Library is no longer purchasing any scientific journals from the West because there is no allocation of "hard currency" funds. Few, if any, other libraries or academic institutions in the former Soviet Union are able to obtain access to key books and journals in the current circumstances. The situation is even more desperate for many sub-Saharan African countries, where purchases of books and journals from abroad ceased several years ago because of lack of funds. . . . The end of conflicts in such countries as Cambodia, Laos, Uganda, Angola, Ethiopia and others has permitted them to turn their attention to the rebuilding of educational and library systems - and there is a desperate need for books of all kinds. ${ }^{49}$

One troubling example of the unidirectional drain of intellectual resources from the Third World is the research area of African oral literatures and traditions. These cultural stories and practices do not belong to any individual; instead, they are the cultural property of ethnic groups or nations. However, as soon as researchers (with most coming from the North) collect this cultural and traditional material, and copyright the resulting compilation, no one can use the 
material without the researcher's permission. ${ }^{50}$ The pattern is becoming depressingly familiar: resources flow out of the Southern regions and are transformed by Northern entrepreneurial authors and inventors into intellectual properties, which in many cases are priced so high that the people from whom such knowledge originated cannot afford to license them.

It is important that intellectual property policy, whether on the domestic or international level, should not be driven solely by the maximalist imperative. The maximalist logic seems to be that if a little bit of protection is good, then a lot will be better, leading us to levels of intellectual property protection spiraling ever upward. There is no consideration of the idea that traditional intellectual property law has been concerned with striking a balance between society's interests and those of individual creators. Reichman importantly reminds us that traditionally intellectual property policy has sought to strike this balance between incentives or rewards to creators and the interests of users, consumers and competitors-the public. Furthermore, by ignoring the importance of this idea of a necessary balance and opting for over-protection, we may "misallocate ... scarce resources devoted to research and development and ... reduce the efficiencies that flow from reverse-engineering and from cumulative, sequential innovation generally." policies that produce oligopolistic barriers block entry for firms in the nations of the least-developed and developing world.

As legal regimes of the world's developed nations steadily expand the scope of property rights in information, many decision makers begin opting for multilateral and supranational intellectual property regimes. As transnational intellectual property regimes begin setting minimum standards of protection, traditional territorial and political notions of sovereignty are eroded. This occurs in large part because entities holding increasingly large blocks of intellectual property rights are not nations, but instead are "private" multinational corporations. The irony is that such entities must then assert the

50. Chakava, supra note 44 , at 20.

Africa's leading fiction writers are published in the North, mostly in Britain, France and the United States. The majority of them sprang into prominence in the $1950 \mathrm{~s}$ and $1960 \mathrm{~s}$ when the African publishing industry was either at its nascent stage, or did not exist at all. They continue to be published in those centers because local African industries are not yet sufficiently developed to provide maximum exposure to their works. ... [This is] a sad reality for the 34 African countries that ascribe to the Berne Convention and constitute the largest members from any continent.

Id. at 19.

51. Fair Followers, supra note 34, at 24. 
"sovereignty" of domestic intellectual property laws to underwrite their ownership claims..$^{32}$ It is on the level of national sovereignty that countries of the least-developed and developing world may be able to make strong arguments for a procompetitive interpretation of TRIPS. It is here that Reichman argues for striking a balance among producers, competitors, users and consumers, with a view towards long-term stabilization, rather than short-term maximum returns, to an increasingly concentrated small number of transnational producers based in the nations of the developed world.

\section{THE QUESTION OF DEFINING AND PROTECTING AN INTELLECTUAL "COMMONS"}

A recent article by Michael Heller entitled, The Tragedy of the Anticommons: Property in the Transition From Marx to Markets ${ }^{53}$ is a very good place to begin looking at some of the questions about how many and what types of intellectual property rights we want to confer, as well as the equally important question of what things do we not want to "propertize" or "thingify." To begin, Heller discusses Garrett Hardin and his famous evocation of the Tragedy of the Commons ${ }^{35}$ that arises when too many people have a privilege to use a resource and no one user has a legal right to exclude any other user-the result is over consumption and depletion of the resource. By contrast, to Heller, a "Tragedy of the Anticommons" occurs when "too many owners hold[] rights of exclusion, the resource is prone to underuse."36 One of the examples Heller uses to demonstrate the "Tragedy of the Anticommons" is post-1989 Moscow storefronts that remain empty, even as

52. Aoki, supra note 19 .

53. Michael A. Heller, The Tragedy of the Anticommons: Property in the Transition from Marx to Markets, 11 HARV. L. Rev. 621 (1998); see also Duncan Kelly \& Frank Michelman, Are Property and Contract Efficient?, 8 HofSTRA L. REV. 711 (1980).

54. Legal realist Felix Cohen gave an example of "thingification" in 1935:

Nobody has ever seen a corporation. What right have we to believe in corporations if we don't believe in angels? To be sure, some of us have seen corporate funds, corporate transactions, etc. .. . But this does not give us the right to hypostatize, to "thingify" the corporation, and to assume that it travels about from State to State as mortal men travel. Felix Cohen, Transcendental Nonsense and the Functional Approach, 35 CoLUM. L. REv. 809, 811 (1935).

55. Garrett Hardin, The Tragedy of the Commons, 162 SCIENCE 1243 (1968). Heller, supra note 53, at 624-25; see also Harold Demsetz, Toward a Theory of Property Rights, 57 AM. ECON. REv. 347 (1967) (discussing how private property rights are one solution to the "Tragedy of the Commons" insofar as they require users to internalize the costs of consuming the resource).

56. Heller, supra note 53, at 624. 
flimsy metal kiosks proliferate. ${ }^{57}$ Underlining the contingency of our property classifications, Heller identifies three key elements of socialist property law that became problems as Soviet law transitioned to a market economy: (1) a hierarchy of property, placing state property with the most protection and socalled "private property" with the least protection; ${ }^{.8}(2)$ the objects of greatest economic value, such as land, were defined as unitary and said to belong to "the people;"'s9 and (3) there were divided, multiple, and overlapping rights to control socialist property that resided in various levels of the state bureaucracy ${ }^{60}-$ no individual "owner" was assigned to a particular object. The problem was that too many "owners" possessed a "right to exclude" related to a particular object of property such that it remained underutilized. ${ }^{61}$

A crucial difference between Hardin's "Tragedy of the Commons" and Heller's "Tragedy of the Anticommons" is what happens with the "right to exclude." ${ }^{12}$ In the commons situation, part of the problem is that no one has the

57. Id. at 631 .

The working hypothesis in this section is that private property emerges less successfully in resources that begin transition [from a socialist to a market economy] with the most divided ownership. In such resources, poorly performing anticommons property is most likely to appear and persist. In contrast, private property emerges more successfully in resources that begin transition with a single owner holding a near-standard bundle of market legal rights.

58. Id. at 628-29.

Socialist law erected a hierarchy based on the level of protection afforded property held by different owners. At top was socialist property, which received the most protection. Next came cooperative property, which received similar but somewhat less protection. Personal property received still less protection. The residual category of private property was abolished altogether in the Soviet Union; the rest of the socialist world gave it the least protection from taxation, regulation, and confiscation.

59. Id. at 629.

[A]ll productive assets were in principle "unitary" and belonged to the "people as a whole," socialist law did not delineate the ordinary physical boundaries.... In the early years of the transition from socialism, private owners and public officials often could not answer the question, "Who controls the land on which we stand?"

60. Id. ("Instead of assigning an owner to each object, socialist law created a complex hierarchy of divided and coordinated rights in the objects it identified [that could be] loosely compare[ed] to Western forms of trust ownership.").

61. Professor Heller gives many other examples of anticommons property, such as the Sergeant Preston of the Yukon-Quaker Oats one-square inch of land giveaway in the 1950s. Other examples include restrictive covenants in deeds or land use permitting processes where multiple parties exercise what could be thought of as the "right to exclude" certain types of development. See id. at 679 n.259.

62. Id.

[F]our categories of rights-holders emerged during the transition. Each of these categories of rights-holders are 'owners' in the sense that they could block other rightsholders from using a store without permission. . . . (a) Owners, ... (b) Users, . . (c) Balance-sheet Holders, ... [and] (d) Regulators. ... The Moscow storefront thus meets 
right to exclude, thereby giving rise to over-utilization and depletion. By contrast, with the anticommons situation, too many parties independently possess the right to exclude, giving rise to under-utilization-tragedy of the anticommons. ${ }^{63}$ In one situation, the "bundle of sticks" comprising property rights lacks a significant "stick"-no one party is able to exclude any other party from the "commons." In the other situation, the significant "stick" (the right to exclude) is broken up and held by many parties-any of whom may exercise the right. Many traditional aspects of U.S. intellectual property law seem to intuitively reflect Professor Heller's observations about the problem of "too many" potential owners. ${ }^{64}$

Id. at $636-39$.

my definition of anticommons property, that is, a property regime in which multiple owners hold rights of exclusion in a scarce resource.

63. Importantly, one should note that Professor Heller states that the anticommons is not always tragic-he points out that "Elinor Ostrom has shown that people may be able to manage non-private property efficiently by developing and enforcing stable systems of informal norms." Id. at 674-75 (citing to ELINOR OSTROM, GOVERNING THE COMMONS: THE EVOLUTION OF INSTITUTIONS FOR COLLECTIVE ACTION 58-102 (1990)). Additionally, Professor Heller points out that:

[S]ome resources may be most efficiently held as anticommons.... [Including] familiar property rights arrangements, such as a scheme of restrictive covenants in a residential subdivision ... [T] the extent that creating such a scheme increases property values more than it imposes negative externalities, the developer's decision to convert raw land to anticommons form can be an efficiency-enhancing move.

Id. (citing Carol Rose, The Comedy of the Commons: Customs, Commerce and Inherently Public Property, 53 U. CHI. L. Rev. 711 (1986)).

64. For example, consider the statutory rules and case law surrounding the works-made-for-hire doctrine, that seeks to clarify and consolidate ownership rights for commissioned works and works made as part of an employment relationship. In the absence of such rules, one could imagine an anticommons situation. See 17 U.S.C $\$ 201$ (1996):

In the case of work made for hire, the employer or other person for whom the work was prepared is considered the author for purposes of this title, and, unless the parties have expressly agreed otherwise in a written instrument signed by them, owns all of the rights comprised in the copyright.

See also the definition of "work made for hire" at 17 U.S.C. \$ 101(1996); Community for Creative Nonviolence v. Reid, 490 U.S. 730 (1989); $c f$. Aymes v. Bonelli, 980 F.2d 857 (2d Cir. 1992) (stating that provisions of employee benefits and tax treatment are the most important factors in determining whether a person is an independent contractor or employee).

Consider also the Joint Works category, for which a deliberate intent must be shown to have created a collaborative work. See 17 U.S.C. $\S 101$ (1996) ("A 'joint work' is a work prepared by two or more authors with the intention that their contributions be merged into inseparable or interdependent parts of a unitary whole."); see also Childress v. Taylor, 945 F.2d 500 (2d Cir. 1991); Margaret Chon, New Wine Bursting From Old Botlles: Collaborative Internet Art, Joint Works, and Entrepreneurship, 75 OR. L. REV. 257 (1996).

Alternately, in terms of creating potential "anticommons" situations in the patent area, consider the "shop right" doctrine, that grants a nonexclusive license to the employer of an inventor who comes up with a patentable invention. See DONALD S. ChISUM \& MiCHAEL A. JACOBS, UNDERSTANDING INTELLECTUAL PROPERTY LAW at § 2g[1] (1992) ("If an employee uses his employer's resources to conceive of or reduce to practice an invention, the employer acquires a 'shop right', a nonexclusive royalty-free, non-transferable license 
Heller mentions how he and his colleague, Rebecca Eisenberg, are working on an anticommons analysis of how expanding the scope of patentable subject matter to include basic biomedical research may lead to the development of fewer useful pharmaceutical products - an underutilization of the information or knowledge. ${ }^{\text {ts }}$ At the very least, one can imagine a variety of licensing schemes in which multiple licensees or holdouts might exercise their licenses to exclude other researchers working along similar lines involving patented technology. Alternately, one might conceive of a situation that conceptually resembles the 1987 Supreme Court case, Hodel v. Irving ${ }^{66}$ (which Heller describes as a spatial anticommons), in which a formerly unitary patent right to a pioneer technology becomes so splintered that the development of the

to make and use the invention."); see also Womack v. Durham Pecan Co., Inc., 715 F.2d 962, 219 U.S.P.Q 1153 (5th Cir. 1983).

Also, consider the geographic scope of a common-law trademark-it is possible for multiple trademark proprietors to have exclusive rights in the same mark in different regions of the country. See DONALD $S$. Chisum \& Michael A. Jacobs, Understanding INTElleCtual Property LAW at § 5E[2] (1992):

At common law, a manufacturer or merchant's trademark rights geographically extended only to markets in which he sold the trademark bearing-goods. Notwithstanding the first use priority rule, a second user could obtain exclusive trademark rights by adopting and using in good faith in a remote market a mark similar or identical to a first user's.

See also Hanover Star Milling Co. v. Metcalf, 240 U.S. 403 (1916); United Drug Co. v. Rectanus Co., 248 U.S. 90 (1918). The federal Lanham Act addresses this problem by instituting a national registry for trademarks. See 15 U.S.C. $\S 1051$ (a) (1997) (providing for registrations for trademarks used in commerce), and (b) (providing for registration of trademarks intended to be used in commerce).

65. See Heller, supra note 53.

In a forthcoming article [Upstream Patents and Downstream Products: A Tragedy of the Anticommons?], Rebecca Eisenberg and I use an anticommons analysis to show how increased patentability of basic biomedical research may lead to the development of fewer useful pharmaceutical products. ... Another intellectual property example occurs in the emerging multimedia field, in which multiple ownership and licensing requirements could create a 'Brady Bunch anticommons.' Use of The Brady Bunch has required agreement from each of the actors portraying Brady kids (and their parents, while the actors were still minors), the Brady parents, and the Brady housekeeper, Alice-as is typical of licensing agreements for such shows.

Id. at 679 n. 259

66. Hodel v. Irving, 481 U.S. 704 (1987); see also Babbitt v. Yuopee, 117 S. Ct. 727 (1997) 
relevant technology is seriously hindered. ${ }^{67}$ Or one might imagine an impasse, such as the case with the development of radio technology prior to World War I, where two economic competitors held key components to radio technology and neither would cross-license to the other. ${ }^{68}$ The impasse was ultimately broken by the U.S. government which needed radio technology in the war effort and managed to force the parties holding blocking patents to work together.

Similarly, granting or expanding proprietary rights in fundamental aspects of things such as the basic information in databases ${ }^{69}$ or functionally necessary

67. Theoretically, at least, the doctrines of denying protection to utilitarian aspects of useful goods and the dichotomy between idea and expression in copyright law work to ensure that the basic ideas remain nonproprietary. Similarly in trademark law, the idea of aesthetic functionality (or functionality in the design patent area) works to keep certain basic design features from becoming proprietary. And the unpatentability of mathematical formula, naturally occurring substances, and the laws of nature works conceptually similarly in Patent. Needless to say, while these doctrines serve to avoid anticommons property situations, at the margins of all of these areas, there is substantial doctrinal confusion about where to draw the line between protection and unprotectability. See generally J. H. Reichman, Legal Hybrids Between the Patent and Copyright Paradigms, 94 COLUM. L. REV. 2432 (1994).

68. David F. NOble, AMERca by Design: Science, Technology and the Rise of Corporate CAPITALISM 93-94 (1997):

By the beginning of World War l, a number of companies had arrived at a stalemate with regard to radio development, due to mutual patent interferences. During the war, when the government guaranteed to protect the companies from infringement suits, research in radio proceeded at a rapid pace. The close of the war, however, brought with it a renewed deadlock. "Ownership of the various patents pertaining to vacuum tubes and circuits by different concerns prevented the manufacture of an improved tube for radio use." In addition to domestic competition, there was a very real possibility that control over radio might be secured by the British Marconi Company, which was trying at the time to obtain rights to the necessary GE-controlled Alexanderson alternator.

In light of this threat to American supremacy of the airwaves, Woodrow Wilson and a number of armed-forces representatives prevailed upon GE to withhold the necessary patent rights and set up instead an American-owned company to control radio. In late 1919, GE thus established the Radio Corporation of America ... and transferred its assets, along with the Alexanderson and other GE-owned patents, to RCA. The industry-wide impasse nevertheless remained, and "the only solution ... was to declare a truce: get together and draw up an agreement defining the rights of the various squatters on the frontiers of science." The truce was declared between AT\&T [that controlled the Lee DeForest-invented vacuum tube] and GE in the license agreement of July 1,1920 , and within the following year . . the other companies in the patent conflict joined the radio-patent pool.... [T] he agreements kept all who were not party to them out of the radio field.

69. See generally Reichman \& Samuelson, supra note 38; see also Samuelson, supra note 38. 
computer program $\mathrm{s}^{70}$ may have the unintended consequence of bringing about a situation of underutilization and lower innovation and competition with regard to those items. Looking to an even earlier time, consider how copyrights in maps and navigational charts were seen as giving rise to either a monopoly on descriptions of geographic and navigational features of coastlines or to an underutilization of navigational charts. ${ }^{71}$ Benjamin Kaplan has pointed out that one reason legal documents (conceived of as legal "maps") have generally not been thought of as possessing thick copyrights is that doing so might create situations where too many people would be drafting around earlier legal documents creating an unacceptable level of unpredictability. ${ }^{72}$ In a sense, to give strong legal protection to legal boilerplate would create an anticommons situations where law firms would expend wasteful amounts of time exercising and policing their "property rights" in legal language.

Similarly, under traditional understandings of trademark law, generic or common descriptions of goods, ${ }^{73}$ mere geographic designations of origin ${ }^{74}$ and surnames ${ }^{75}$ were not considered susceptible to proprietorship without a showing that they had acquired "secondary meaning" in the minds of relevant consumers. ${ }^{76}$ Until recently, trade dress, those aspects of a product that

70. See generally Pamela Samuelson, Fair Use for Computer Programs and Other Copyrightable Works in Digital Form: The Implications of Somy, Galoob \& Sega, 1 J. INTELL. PROP. L. 49 (1993); Sega Enters., Ltd. v. Accolade, Inc., 977 F.2d 1510 (9th Cir. 1992); Atari Games Corp. v. Nintendo of Am., Inc., 975 F.2d 832 (Fed. Cir. 1992).

71. Mason v. Montgomery Data Inc., 967 F.2d 135 (5th Cir. 1992) (finding about the maps in question that (1) the merger doctrine did not apply (idea and expression merge, and expression is unprotectable) and (2) they possessed sufficient originality to qualify for copyright protection); see also U.S. v. Hamilton, 583 F.2d 448 (9th Cir. 1978); Jane C. Ginsburg, Creation and Commercial Value: Copyright Protection of Works of Information, 90 Colum. L. Rev. 1865 (1990). But see David B. Wolf, Is There Any Copyright Protection for Maps after Feist?, 39 J. COPYRIGHT SOC'Y 224 (1992); Kem River Gas Transmission Co. v. Coastal Corp., 899 F.2d 1458, 1460 (5th Cir. 1990) (stating that because the idea and its expression embodied in plaintiff's maps are inseparable, "the maps at issue are not copyrightable"), cert. denied, $111 \mathrm{~S}$. Ct. 374 (1990).

72. BENJAMIN KAPLAN, AN UNHURRIED VIEW OF COPYRIGHT 64-65 (1967) (criticizing the Continental Casualty Co. v. Beardsley case in which the Second Circuit found copyright infringement liability for use of an insurance claim form. Kaplan wrote, "the effect of the decision may be to force users to awkward and possibly dangerous recasting of the legal language to avoid infringement actions.").

73. King-Seeley Thermos Co. v. Aladdin Industries, Inc., 321 F.2d 577(2nd Cir. 1963); Anti-Monopoly, Inc. v. General Mills Fun Group, 684 F.2d 1316 (9th Cir. 1982).

74. 15 U.S.C. $\$ 1052$ (e) (2) (1997); American Waltham Watch Co. v. United States Watch Co., 173 Mass. 85 (Mass. 1899); In re Nantucket, Inc., 677 F.2d 95 (C.C.P.A. 1982); In re House of Windsor, Inc., 221 U.S.P.Q. 53 (T.T.A.B. 1983). 1975).

75. 15 U.S.C. $\$ 1052$ (e)(4)(1997); In re Application of Harris-Intertype Corp., 518 F.2d 629(C.C.P.A.

76. Zatarain's, Inc. v. Oak Grove Smokehouse, Inc., 698 F.2d 786 (5th Cir. 1983); In re Application of Synergistics Research Corp., 218 U.S.P.Q. 165 (T.T.A.B. 1983). 
involved its shape or packaging, was not considered protectable unless it was nonfunctional or inherently distinctive. Until the Two Pesos case in $1992,{ }^{77}$ it was necessary to show a secondary meaning as well. After Two Pesos, no showing of secondary meaning is required, thereby expanding the scope of trade dress protection. These doctrines were all common-sense recognitions that allowing property ownership (the right to exclude) to vest in things like ideas, ${ }^{78}$ facts, ${ }^{79}$ mathematical formulas, ${ }^{80}$ laws of nature, ${ }^{81}$ and common descriptive words or phrases would lead to underutilization of intellectual works incorporating those preexisting, fundamental building blocks. ${ }^{82}$ Intuitively and implicitly, the traditional intellectual property understandings of what was considered to be in the public domain was seemingly an attempt to avoid a "tragedy of the anticommons."

One key difference between Moscow storefronts and patents or copyrights is that intellectual property rights do not involve a tangible boundary, but rather a conceptual boundary - a boundary demarcated by the legal line between that which is considered to be in the public domain (ideas; functional aspects of useful goods and facts distinguished from original authorial expressions in copyright; mathematical formulas; laws of nature distinguished from novel, nonobvious, useful innovations in patent; and surnames and geographically descriptive and common or generic terms distinguished from arbitrary, fanciful, distinctive marks with secondary meaning in trademark law) and the private domain. Another key difference between physical property and intellectual

77. Two Pesos, Inc. v. Taco Cabana, Inc., 112 S. Ct. 2753 (1992) (stating that proof of secondary meaning not required under a Lanham Act $\S 43$ (a) claim when trade dress is inherently distinctive). See 15 U.S.C. $\$ 1125$ (1996) (often referred to as a federal unfair competition law, because $\S 43$ (a) does not require registration on the principal register).

78. 17 U.S.C. $\$ 102$ (b) (1996) ("In no case does copyright protection for an original work of authorship extend to any idea, procedure, process, system, method of operation, concept, principle, or discovery, regardless of the form in which it is described, explained, illustrated, or embodied in such work."); see also Baker v. Selden, 101 U.S. 99 (1879); Mazer v. Stein, 347 U.S. 201 (1954); Lotus Dev. Corp. v. Borland Int'l, Inc., 49 F.3d 807 (1st Cir. 1995), aff'd (4-4), 116 S. Ct. 804 (1996).

79. Feist Publication, Inc. v. Rural Telephone Service Co., 499 U.S. 340 (1991); see also Bell South Advertising \& Publishing Corp. v. Donnelley Information Publishing, Inc., 999 F.2d 1436 (11th Cir. 1993); Jane C. Ginsburg, Sabotaging and Reconstructing History: A Comment on the Scope of Copyright Protection in Works of History After Hoehling v. Universal City Studios, 29 J. COPYRIGHT SOC'Y 647 (1982).

80. Compare Gottschalk v. Benson, 409 U.S. 63 (1972), with Diamond v. Diehr, 450 U.S. 175 (1981).

81. Compare Funk Bros. Seed Co. v. Kalo Innoculant Co., 333 U.S. 127 (1948), with Diamond v. Chakrabarty, 447 U.S. 303 (1980).

82. See David Lange, Recognizing the Public Domain, 1981 LAW \& ConteMP. Probs. 147 (1981); Jessica Litman, The Public Domain, 39 EMORY L. J. 965 (1990); Keith Aoki, Authors, Investors and Trademark Owners: Private Intellectual Property and the Public Domain, Part I and II, 18 CoLUM. J. L. \& ARTS. 1-73, 191-267 (1993-1994). 
property is that the supply of storefronts or grazing land is physically finite. As Heller points out, if one continues drawing boundaries and parceling out property rights, one eventually ends up with a spatial anticommons.

Elsewhere, I have discussed the "public goods" aspects of intellectual property, ${ }^{83}$ but the main relevant point is that intellectual property seems infinite, as though it were created ex nihilo, pulled from the empty ether by the fevered imagination or intellect of a transformative artistic or scientific genius. As James Boyle has articulately pointed out, it is this vision of romantic creativity that makes our common sense traditional intellectual property law and doctrines expand consistently, if not always in the direction of greater protection. ${ }^{84}$ This expansion tends to make us ignore the common-sense knowledge that new intellectual creations are formed from preexisting thoughts and ideas in a long chain stretching back into antiquity. This particular and peculiar vision of creativity makes it seem that expanding the scope and increasing the types of intellectual property are without cost because the supply of new ideas and works is apparently infinite. I say that this is apparent, because as Heller points out, there is a point where too many property rights owned by too many parties creates a legal "smog," that is, an anticommons. When we reach this situation, a serious and consequentialist rethinking and rebundling of property rights may be necessary so that we may connect the purpose and intent of our intellectual property (or other) laws with their effects- to "promote the Progress of Science and the useful Arts." ${ }^{85}$ Thus, the nonphysicality of intellectual property may matter less here than the idea of the scope of initial intellectual property entitlement as well as how the rights to control are bundled.

Reichman argues that we are able to recognize these types of concerns, and to tailor our legal system to address them. Observed in this light, the landmark Feist case might be seen in part as an attempt to avoid a "tragedy of the anticommons"-an attempt to make sure that the threshold for copyright

83. See generally Aoki, supra note 82, at 19-22; see also Paul A. Samuelson, The Pure Theory of Public Expenditure, 36 REV. ECON. \& STAT. 387 (1954).

84. BOYLE, supra note 1. See also Mark A. Lemley, Romantic Authorship and the Rhetoric of Property, 75 TEX. L. ReV. 873 (1997) (reviewing JAMEs BOYLE, Shamans, SOFTWARE, AND SPLEENS: LAW AND THE CONSTRUCTION OF THE INFORMATION SOCIETY(1996)). See generally Peter Jaszi, Toward a Theory of Copyright: The Metamorphoses of "Authorship," 1991 DUKE L. J. 455 (1991); MARTHA WOODMANSEE, THE AUTHOR, ART, AND THE MARKET: REREADING THE HISTORY OF AESTHETICS (1994); MARK ROSE, AUTHORS AND OWNERS: THE INVENTION OF COPYRIGHTS (1993); PAUL GOLDSTEIN, COPYRIGHT'S HIGHWAY: From Gutenberg to tHE Celestial JuKeboX (1994).

85. U.S. CONST. art. $1, \S 8, \mathrm{cl} .8$. 
ownership was not set so low that all sorts of infringement claims would arise, resulting in the underutilization of facts and data from public domain sources. However, note that while the questions of commons or anticommons property has not been generally addressed when considering expanding the scope of patent rights, whether through the doctrine of equivalents ${ }^{86}$ or through statutory interpretation of subject matter categories (e.g., medical procedures or sports moves $^{87}$ ) within the United States, perhaps it should be.

There is another wrinkle in considering the expanding scope of domestic intellectual property protection and the "public domain." In many ways, our current conception of the public domain is that nobody affirmatively owns public domain materials. It is this unowned characterization that is somewhat at odds with a characterization of the public domain of intellectual materials as

86. See Hilton Davis Chemical Co. v. Wamer-Jenkinson Co., 62 F.3d 1512 (Fed. Cir. 1995) (holding that in every patent infringement case, the court must apply the doctrine of equivalents); see also Peter $\mathrm{K}$. Schalestock, Equity for Whom? Defining the Reach of Non-Literal Patent Infringement, 19 SEATTLE U.L. REV. 323 (1996); Mark A. Lemley, The Economics of Improvement in Intellectual Property Law, 75 TEX. L. REV. 989 (1997). William W. Fisher III, The Growth of Intellectual Property: A History of the Ownership of Ideas in the United States 5-6 (Sept. 4, 1997)(on file with the INDIANA JOURNAL OF GLOBAL LEGAL. STUDIES).

87. Nineteenth century cases held that medical procedures were not patentable for policy grounds. See Morton v. New York Eye Infirmary, 17 F. Cas. 879, 881 (C.C.S.D.N.Y.) (No. 9,865) (holding that a method of performing surgery "combining therewith the application of ether" developed by two surgeons during the Civil War was not patentable). Note that the PTO has changed its position and has indicated that medical methods are patentable as processes if they meet the conditions of utility, nonobviousness and novelty. See Ex Parte Scherer, 103 U.S. P.Q. (BNA) 107 (Pat. Off. Bd. App. 1954) (upholding a patent for a method of injecting medicine via pressure jet); Edward Felsenthal, Medical Patents Trigger Debate Among Doctors, WALLST. J., August 11, 1994, at B1; Joel J. Garris, The Case for Patenting Medical Procedures, 22 AM. J.L. \& MED. 85 (1996); Jeffrey Lewis, No Protection for Medical Processes: International Posture May Be Hurt by New Law, New York LAw. J., March 10, 1997, at S1. See also U.S. Patent No. 4,960,129 (patenting method for diagnosing heartbeat disorders); U.S. Patent No. 5,026,538 (patenting method for treating arthritis); U.S. Patent No. 5,320,094 (patenting method for administering insulin); Robert M. Kunstadt, et al., Are Sports Moves Next in IP Law?, National L.J., May 20, 1996, at C2:

Although the norms of sports enthusiasts might be offended, sports is now big business, and big business demands this protection. Entire industries exist to sell and promote goods and services at sporting events and for use by sports participants. Players in this vast market may benefit from the efficiency of fixed property rights in the fuel that drives these market transactions. A key element of that fuel is the sports moves themselves, and patents, copyrights and trademarks may provide the best tools for securing those rights.

See also Fisher, supra note 86, at 4-5. 
a commons. $^{88}$

For example, Carol Rose has raised a set of extremely cogent arguments in response to Hardin's Tragedy of the Commons. Rose has described how in certain situations the solution to depletion or overutilization of scarce resources may not be to bestow private property rights, but to deploy common law and statutory strategies that she has referred to as involving the Comedy of the Commons. ${ }^{89}$ The situations that Rose refers to involve what is thought of as "public property." Rose points to the long Western legal pedigree of the idea of "public property," or jus publicum. ${ }^{90}$ Traditionally, due to their "inherent publicness," certain types of property-land between high and low tides, roadways, land underlying navigable waterways, and other such properties-were conceived of as being subject to a public easement for fishing, commercial and navigation purposes. ${ }^{91}$ During the 1970 s, 1980 s, and 1990 s,

88. Carol M. Rose, The Comedy of the Commons: Custom, Commerce, and Inherently Public Property, 53 U. CHI. L. REV. 71 1, 721 (1996) [hereinafter Comedy of the Commons] ("[P]roperty in . . . an unorganized public would amount to an unlimited commons, which seems not to be property at all, but only a mass of passive 'things' awaiting reduction to private property through the rule of capture or, worse yet, their squandering in the usual "tragedy of the commons."). See also Carol M. Rose, A Dozen Propositions on Private Property, Public Rights, and the New Takings Legislation, 53 WASH. \& LEE L. REV. 265 (1996) [hereinafter $A$ Dozen Propositions].

89. Comedy of the Commons, supra note 88.

90. Id. at 713. See also Alfred C. Yen, Restoring the Natural Law: Copyright as Labor and Possession, 51 OHIOST. L.J. 517 (1990) ("The idea/expression dichotomy's roots in res communes and ferae naturae provide the most obvious was in which the natural law creates a public domain. . . [T] prohibited property claims in those objects which were by nature difficult to possess . . [and imply] that copyright should not be extended to those facets of a work which are difficult to possess."); Daniel $\mathbf{R}$. Coquillette, Mosses From an Old Manse: Another Look at Some Historic Property Cases About the Environment, 64 CORNell L. REV. 761 (1979); Harry N. Schneiber, Public Rights and the Rule of Law in American Legal History, 72 CaL. L. Rev. 217 (1984); Molly Selvin, The Public Trust Doctrine in American Law and Economic Policy, 1789-1920, 1980 WIS. L. REv. 1403.

91. Comedy of the Commons, supra note 88, at 713-14. See also Illinois Cent. R.R. Co. v. Illinois, 146 U.S. 387 (C.C.S.D. Ill. 1892) (Field, J.):

That the State holds the title to the lands under the navigable waters of Lake Michigan, within its limits, in the same manner that the State holds title to soils under tide water, by the common law, we have already shown.... But it is a title different in character from that which the State holds in lands intended for sale. ... It is a title held in trust for the people of the State that they may enjoy the navigation of the waters, carry on commerce over them, and have liberty of fishing therein freed from the obstruction or interference of private parties.

Id. at 452. For an updated application of the Public Trust Doctrine applied to lakefront property owned by Loyola University in Chicago, see Lake Michigan Fed'n v. United States Army Corps of Eng'r, 742 F. Supp. 441, $445-447$ (N.D. Ill. 1990):

Three basic principles can be distilled from this body of public trust case law. First, courts should be critical of attempts by the state to surrender valuable public resources to a private entity. ... Second, the public trust is violated when the primary purpose of a legislative grant is to benefit a private interest. ... Finally, any attempt by the state to 
state courts began using these older precedents, some dating back to the midnineteenth century, to carve out a growing set of "public rights" that served to limit what private property owners could do with their property. ${ }^{92}$ In particular, the public easement for fishing, commerce and navigation has been expanded to include recreational uses, and in some cases has been extended to include dry sand areas of beaches. ${ }^{93}$ Rose observes:

Like the older precedents, the new beach cases usually employ
one of three theoretical bases: (1) a "public trust" theory, to
the effect that the public has always had rights of access to the

relinquish its power over a public resource should be invalidated under the doctrine.... What we have here is a transparent giveaway of public property to a private entity. The lakebed of Lake Michigan is held in trust for and belongs to the citizenry of the state. The conveyance of lakebed property to a private party-no matter how reputable and highly motivated that private party may be-violates this public trust doctrine.

92. See Marks v. Whitney, 491 P.2d 374 (Cal. 1971)(extending the Public Trust Doctrine to encompass preservation of tidelands in their natural state in the face of the tideland owner's desire to fill them in, and recognizing that Public Trust may protect other interests such as wildlife habitat, water quality, recreation, and aesthetics). See also National Audubon Soc'y v. Superior Court of Alpine County, 658 P.2d 709 (Cal. 1983) (California Supreme Court rejected a takings challenge to a permit granted by the California Water Board to the City of Los Angeles to draw down five tributaries feeding Mono Lake (because of drawdowns, Mono lake had shrunk to a third of its former size)-the Court held that the State of California lacked the authority to grant absolute water rights that would cause substantial ecological damage); Just v. Marinette County, 201 N.W.2d 761 (Wis. 1972) (extending Public Trust Doctrine to wetlands and preventing private owner from infilling); Joseph L. Sax, The Limits of Private Rights in Public Waters, 19 ENVTL. L. 473 (1989); Richard J. Lazanus, Changing Conceptions of Property and Sovereignty in Natural Resources: Questioning the Public Trust Doctrine, 71 lowa L. Rev. 631 (1986); Joseph L. Sax, The Public Trust Doctrine in Natural Resource Law: Effective Judicial Intervention, $68 \mathrm{MICH}$. L. REv. 471 (1970). But cf. James L. Huffman, A Fish Out of Water: The Public Trust Doctrine in a Constitutional Democracy, 19 ENVTL. L. 527 (1989); James L. Huffman, Avoiding the Takings Clause Through the Myth of Public Rights: The Public Trust and Reserved Rights Doctrines at Work, 3 J. LAND USE \& ENVTL. L. 171 (1987).

93. Comedy of the Commons, supra note 88, at 713-14. For cases expanding public access to waterfront properties, see, e.g., Stevens v. City of Cannon Beach, 854 P.2d 449 (Or. 1993), cert. denied, 114 S. Ct. 1332 (1994) (Scalia, J. and O'Connor, J., dissenting from denial of certiorari); Matthews v. Bay Head Improvement Ass'n, 471 A.2d 355 (N.J. 1984) (using Public Trust Doctrine); City of Berkeley v. Superior Court, 606 P.2d 362 (Cal. 1980), cert. denied, 449 U.S. 840 (1980) (holding that $19^{\text {th }}$ century "inherently public" tidelands did not convey title free of the public trust, however, lands filled in the past, now free of trust); Van Ness $v$. Borough of Deal, 393 A.2d 571 (N.J. 1978); City of Daytona Beach v. Tona-Rama, Inc., 294 So.2d 73 (Fla. 1974) (using prescription theory); Gion v. Santa Cruz, 465 P.2d 50 (Cal. 1970) (using theory of "implied dedication," but subsequently legislatively overruled); Borough of Neptune City v. Borough of Avon-By-TheSea, 294 A.2d 47 (N.J. 1972) (using Public Trust Doctrine); State ex rel. Thornton v. Hay, 462 P.2d 671 (Or. 1969) (using idea of custom to support access). But cf. McDonald v. Halvorson, 780 P.2d 714 (Or. 1989) (applying custom only to beaches where actual public use could be demonstrated); Opinion of the Justices, 313 N.E.2d 561 (Mass. 1974) (rejecting New Jersey Public Trust Doctrine approach); Bell v. Town of Wells, 557 A.2d 168 (Me. 1989) (limiting Public Trust Easement in tidelands strictly to those uses reserved in colonial ordinances from 1641: fishing, fowling and navigation). 
property in question, and that any private rights are subordinate to the public's "trust" rights; (2) a prescriptive or dedicatory theory, by which a period of public usage gives rise to an implied grant or gift from private owners; and (3) a theory of "custom," where the public asserts ownership of property under some claim so ancient that it antedates any memory to the contrary. ${ }^{94}$

Rose goes on to observe that these cases seemingly contradict traditional economic analysis by inverting the logic of viewing private property as the optimal solution to the tragedy of the commons. At first blush, these cases take private property and turn it into a commons, in which anyone and everyone can overuse and despoil such properties-the right to exclude has been taken from the owner's bundle of sticks. This raises the question whether, " $[\mathrm{A}]$ ny property inherently or even presumptively [should be] withdrawn from exclusive private expropriation?"'ss

To answer this question, Rose points to two traditional exceptions to the general preference favoring private property ownership: (1) “"plenteous' goods. ... [T] hings that are either so plentiful or so unbounded that it is not worth the effort to create a system of resource management ... [f]or which the difficulty of privatization outweighs the gains in careful resource management," ${ }^{, 96}$ and, (interestingly for intellectual property purposes); (2) public goods "where many persons desire access to or control over a given property, but they are too numerous and their individual stakes too small to express their preferences in market transactions. ${ }^{997}$ Interestingly, note that intellectual property possesses two characteristics of a "public good:" jointness of supply and impossibility of exclusion.

While the analogy between real property and intellectual property is incomplete and discontinuous in many ways, some of the logic of the "public trust" and "custom" cases, such as National Audubon Society v. Superior Court of Alpine County (the "Mono Lake" case)" in 1983 and Stevens v. City

94. Comedy of the Commons, supra note 88, at 714.

95. Id. at 717 .

96. Id.

97. Id. at 719.

98. National Audubon Soc'y, 658 P.2d at 709 (1983). 
of Cannon Beach in 1993,99 may be helpful in framing questions of the intellectual public domain. In the Mono Lake case, the California Supreme Court stated that the State of California lacked the authority to grant the City of Los Angeles absolute water rights which had significant ecological impact (drawing down the water level in Mono Lake by diverting five feeder streams to Los Angeles and shrinking Mono Lake by over a third in size) on areas that were subject to the public trust. ${ }^{100}$ In the Stevens case, the Oregon Supreme Court held that the denial of a building permit to build a seawall on the dry sand area of a beach was not a taking under the Just Compensation Clause, and that maintenance of public access to the dry sand beach had arisen pursuant to the doctrine of custom. ${ }^{101}$ The Stevens case was appealed to the U.S. Supreme Court, which denied certiorari over a strong dissent from Justices Scalia and O'Connor. ${ }^{102}$ What significance might a salt lake in California and a stretch of dry sand beach in Oregon hold for intellectual property law?

First, the logic of both opinions suggests that certain types of land possessing unique characteristics are subject to the public trust. A baseline presumption in U.S. property law is that all property rights within the United States originate from the United States or some predecessor sovereign. When the federal sovereign passed these property rights either to the state sovereigns or to private individuals, it retained or reserved the stick in the property rights

99. Stevens, 854 P.2d 449, cert. denied, 114 S. Ct. 1332, 1335 (1994) (Scalia, J. and O'Connor, J., dissenting from denial of certiorari).

100. National Audubon Soc'y', 658 P.2d at 724.

[T] he public trust is more than an affirmation of state power to use public property for public purposes. It is an affirmation of the duty of the state to protect the people's common heritage of streams, lakes, marshlands and tidelands, surrendering that right of protection only in rare cases when the abandonment of that right is consistent with the purposes of the trust.

101. Stevens, 854 P.2d at $456-57$

When plaintiffs took title to their land, they were on notice that exclusive use of the dry sand areas was not a part of the "bundle of rights" that they acquired, because public use of dry sand areas "is so notorious that notice of the custom on the part of persons buying land along the shore must be presumed." ...We, therefore, hold that the doctrine of custom as applied to public use of Oregon's dry sand areas is one of "the restrictions that background principles of the State's law of property . . . already place upon land ownership." ... We hold that plaintiffs have never had the property interests that they claim were taken by defendants' decision and regulations.

102. Stevens, 854 P.2d 449, cert. denied, 114 S. Ct. 1332, 1335 (1994) (Scalia, J. and O'Connor, J., dissenting from denial of cert.):

To say that this case raises a serious Fifth Amendment takings issue is an understatement. The issue is serious in the sense that it involves a holding of questionable constitutionality; and it is serious in the sense that the land-grab (if there is one) may run the entire length of the Oregon coast. 
bundle pertaining to use and maintenance of those properties, consistent with the public trust. To the extent that private property owners use their property contrary to the public trust, state government may move in to regulate or prohibit those uses in the name of exercising its reserved public trust responsibilities, thereby acting as trustee for members of the public. Additionally, when acting pursuant to the public trust, no "taking" occurs because the "right" to use private property contrary to the public trust was never a part of the bundle of sticks that we call property ownership in the first place, but was reserved by the sovereign. Similarly, in the Stevens case, expectations that had arisen over the course of a long period of time about public beach access were recognized, and the judicial (or legislative) recognition of these customary rights effected no "taking" either because the property owner took title subject to, and with notice of, the "custom" of beach access in Oregon.

The relevance for intellectual property law is that instead of geographic features of land (beaches, lakes, and wetlands), there may be categories of information that could be conceived of as possessing characteristics of public trust property. One problem with our intellectual property law, and copyright law in particular, is that it, on a general level, treats all copyrightable subject matter the same. For example, a song by Kurt Cobain is different from a scientific treatise, DOOM is different from a first grade textbook about the alphabet, an X-Men comic book is different than Lotus 1-2-3. Perhaps there are some categories of uses that might be worth granting an "easement"-like right in members of the public (or for that matter, publishers in the Third World).

The structure of the argument would proceed through several steps. First, because the U.S. Constitution mandates "securing for limited times to authors and inventors the exclusive rights to their respective writings and discoveries" in order to "promote the Progress of Science and useful Arts," there is a link between the positivist property rights granted and a constitutionally mandated public purpose. Second, one might argue that this grant is from the sovereign to "authors and inventors" only to the extent that promotion of that public purpose (advancing science and the useful arts) is achieved. Furthermore, such a conditioned grant presupposes a reservation of power in the sovereign when the actual effects of such a grant work against those public purposes. A shadow of this reasoning can be seen in copyright and patent misuse cases. The grant of exclusive rights to authors and inventors never included the right to use that grant for anticompetitive purposes that are contrary to antitrust laws-it was never a stick in the bundle of rights that comes with a patent or a 


\section{copyright. ${ }^{103}$ Another shadowy example is copyright law's fair use doctrine and patent law's reverse doctrine of equivalent exceptions-one might conceive of "fair use" or "reverse doctrine of equivalents" as a species of "easement" in the name of the public. ${ }^{104}$ \\ Third, this line of reasoning embodies some broad-based public trust-type}

103. In the patent misuse area, see Brulotte v. Thys Co., 379 U.S. 29 (1964) (refusing use of licenses beyond term of patent); Dawson Chem. Co. v. Rohm \& Haas Co., 448 U.S. 176 (1980) (tying unpatented products to patented products to capture the market for both); U.S. Dept. of Justice Guidelines for the Licensing and Acquisition of Intellectual Property $\$ 5.6$ (Aug. 8, 1994) (unpublished manuscript, on file with the author) (prohibiting certain types of "grant back" clauses that require a patent licensee to "grant back" to the licensor any improvement patents). See generally Mark A. Lemley, Note, The Economic Irrationality of the Patent Misuse Doctrine, 78 CAL. L. REV. 1599 (1990).

In the area of copyright, misuse is relatively recent. In particular, since 1990 , there have been a number of cases finding a plaintiff's copyright unenforceable because of misuse. See DSC Communications Corp. v. DGI Technologies, Inc., 81 F.3d 597 ( $5^{\text {th }} \mathrm{Cir}$. 1996) (finding copyright misuse appropriate where copyright owner tried expanding the copyright beyond its scope into a patent-like monopoly); Bateman v. Mnemonics, Inc., 79 F.3d 1532, 1547 (1 $1{ }^{\text {th }}$ Cir. 1996) (suggesting that copyright misuse was relevant to prevent an owner of a copyright from gaining protection for an idea in violation of 17 U.S.C. \$102(b)); Lasercomb America, Inc. v. Reynolds, 911 F.2d 970, 978 (4 $4^{\text {th }}$ Cir. 1990) (describing copyright misuse as "an equitable defense to an infringement action . . . [when] the copyright is being used in a matter violative of . . the public policy embodied in the grant of a copyright."); Qad Inc. v. ALN Assocs., Inc., 770 F. Supp. 1261 (N.D. Ill. 1991); Timothy H. Fine, Misuse and Antitrust Defenses to Copyright Infringement Actions, 17 Hastngas L.J. 315 (1965); Marshall Leaffer, Engineering Competitive Policy and Copyright Misuse, 19 U. DAYTON L. REV. 1087 (1994); James A. D. White, Misuse or Fair Use: That Is the Software Copyright Question, 12 BERKELEY TECH. L.J. 251 (1997); Ramsey Hanna, Note, Misusing Antitrust: The Search for Functional Copyright Misuse Standards, 46 STAN. L. REV. 401 (1994).

These additional issues arise in terms of contract and license terms that conflict with a user's legitimate interests under the copyright statute. There are many open questions about the validity of software contracts that purport to prohibit reverse engineering and decompilation of licensed software. There have been a series of cases that have allowed some degree of reverse engineering in certain circumstances. See Lotus Dev. Corp. v. Borland Int'l, 49 F.3d 807, 818 (1 ${ }^{\text {मd }}$ Cir. 1995); Sega Enter. Ltd. v. Accolade, Inc., 977 F.2d 1510, 1527-8 (9 $9^{\text {th }}$ Cir. 1992); Atari Games Corp. v. Nintendo of America, Inc. 975 F.2d 832, 843-4 (Fed. Cir. 1992); Vault Corp. v. Quaid Software Ltd., 847 F.2d 255, 270 ( $5^{\text {th }}$ Cir. 1988). See also Julie E. Cohen, Reverse Engineering and the Rise of Electronic Vigilantism: Intellectual Property Implications of "Lock-Out" Programs, 68 S. CAL. L. REV. 1091 (1995); Samuelson, supra note 70. Contracts and licenses may also ask licensees to waive other rights provided by the copyright statute, such as the $\S 117$ right to copy and adapt a program to work on a particular machine. 17 U.S.C. $\$ 117$ (1994). Or licenses may forbid licensees from transferring copies of the copyrighted work in ways that conflict with the "first sale" doctrine of $\S 109$ (a). See 17 U.S.C. \$109(a)-(b)(1)(A)(1994). There are also nonwaivable rights granted by the copyright statute, such as the right of authors of older works to terminate transfers of rights in a copyrighted work between 35 and 40 years after the work was created. See generally Mark A. Lemley, Beyond Preemption: The Federal Law and Policy of Intellectual Property Licensing, Cal. L. Rev. (forthcoming January 1999).

104. Some other examples of areas where lower (or nonexistent) levels of per se intellectual property protection have actually helped spur competitiveness and innovation are: clothing designs (which are noncopyrightable, although trade dress protection may apply for confusingly similar garments); utilitarian aspects of useful goods; architectural designs prior to 1992 (when architectural works became copyrightable); university-sponsored scientific research prior to 1984 (when the federal government directed that such research be patented); and legal documents (which while copyrightable, are seldom asserted) and judicial opinions. 
of responsibility reserved to the federal government to keep certain information (for example, some types of basic scientific research, information in databases, educational purposes and uses, new medical techniques, or even human genomic material) ${ }^{105}$ available and open to benefit both the public and private owners. Lastly, an important point is that this line of reasoning conceptualizes information in the public domain not as "unowned," but as owned by everyone. Part of the tragedy of the commons was that no one asserted the public right to maintain the commons-the default position seemed to be a powerless local government. As Rose has shown, public and private property rights work in tandem to maintain a vibrant free-enterprise system. ${ }^{106}$ Duncan Kennedy and Frank Michelman have argued that:

[While] much legal and related policy-analytic literature reflects and reinforces the view that certain legal institutions (e.g., private property, free contract) are in some sense generally or presumptively efficient, while others (e.g., central regulatory command, commonses) are generally or presumptively inefficient... [A]ny actually efficient regime, though it may well contain rules fairly characterizable as private property and free contract, must contain them in combination with rules drawn from realms perceived as opposite to private property/free contract (viz., unowned commonses and collective controls) so that there is no more reason for awarding the palm of "presumptive efficiency" to private property/free contract than to its opposites. ${ }^{107}$

105. The copyright statute already has a plethora of odd, seemingly unconnected exemptions. See 17 U.S.C. $\$ 110(6)$ (1994) (exempting from copyright infringement liability a "performance of a nondramatic musical work by a governmental body or a nonprofit agricultural or horticultural . . . fair or exhibition conducted by such body or organization ..."); 17 U.S.C. $\$ 110(1)(1994)$ (exempting a "performance or display of a work by instructors or pupils in the course of face-to-face teaching activities of a nonprofit educational institution, in a classroom or similar place devoted to instruction ...").

106. A Dozen Propositions, supra note 88, at 267.

[H] istoric Anglo-American legal principles did indeed recognize the importance of private property rights, which are essential in a functioning free enterprise economy. But those principles also recognized what were called "public rights," particularly in resources that are not easily turned into private property-historically, air, water resources, and fish and wildlife stocks - because the management of such diffuse resources is also essential in a functioning economic order of free enterprise.

107. Kennedy \& Michelman, supra note 16, at 714. 
Perhaps, some types of information may be so conceptually similar to things like land underlying navigable waterways, beaches and coastal areas, and the electromagnetic spectrum, that too many private property rights give rise to "common pool" problems that are only addressable through some type of regulatory regime that ensures continued access for the public. Note that in this formulation, the anticommons problem does not arise because "everyone" does not possess the "right to exclude" as was the case with Moscow storefronts, but the "public" (via the government) may be able to prevent private parties from making maximalist property claims that harm the promotion of science and useful arts. Additionally, rather than conceptualizing the intellectual public domain as unowned (a sort of default zone where things that are so rudimentary or useless come to lie), we may be able to conceptualize it as an intellectual zone where things that are too important to be owned by one party reside. They are, in effect, owned by the public.

There are three major criticisms of this approach. First, it is unclear (even in the real property area) whether the federal government is subject to the public trust doctrine. To date, it has been largely a creature of state common law and has been quite controversial over the past three decades. ${ }^{108}$ Indeed, I am not even arguing that public trust doctrine be applied to intellectual property, only that it may provide a different perspective on conceptualizing intellectual property rights. Second, there are large definitional problems in terms of delineating categories of creations that might be subject (educational, scientific, and so on)-how narrowly or broadly should possible categories be defined to this "intellectual public trust," particularly given the paradigmatic institutional capture by the agropharmaceutical and copyright industries of the U.S. Copyright and Patent and Trademark Office in the 1990s. Finally, questions of standing to sue would be very problematic in terms of who would be empowered to assert the "public trust." There are an increasing number of organizations that are possible candidates, such as the Taxpayer Assets Project (headed by James Love), the Electronic Frontier Foundation or the Digital Future Coalition that opposed the adoption in 1996 of the WIPO Database Protection Proposal.

I do not offer these observations to introduce a ready-for-implementation

108. See District of Columbia v. Air Florida, Inc., 750 F.2d 1077, 1082-83 (D.C. Cir. 1984) ("In this country the public trust doctrine has developed almost exclusively as a matter of state law.... [N]either the Supreme Court nor the federal courts of appeals have expressly decided whether public trust duties apply to the United States."); see also Charles F. Wilkinson, The Public Trust Doctrine in Public Land Law, 14 U.C. DAVIS L. REV. 269 (1980). 
legislative or judicial proposal-far from it. I believe that some of the ultimate goals that underlie the public trust doctrine in the environmental law area may have some deep connections with how we are administering and constructing our information environment-in particular, how we talk about "property," intellectual or otherwise. A privatized information environment that is unable to contemplate any other standard for measuring its worth other than market efficiency may be, on many levels, a dystopian environment indeed.

James Boyle has recently written of the analogies between the nascent state of environmental law in the early 1960 s, when public consciousness of the dangers of environmental degradation began dawning, and the current state of public consciousness of intellectual property laws. ${ }^{109}$ Boyle has called for an "environmentalism for the Net" in terms of the need for activism in the name of protecting and maintaining a healthy balance of public and private rights in the digital environment. Boyle points out:

In both environmental protection and intellectual property, the very structure of the decision-making process tends to produce a socially undesirable outcome. Decisions in a democracy are made badly when they are primarily made by and for the benefit of a few stakeholders, be they landowners or content providers. It is a matter of rudimentary political science analysis or public choice theory to say that democracy fails when the gains of a particular action can be captured by a relatively small and well-identified group while the losses-even if larger in the aggregate-are low-level effects spread over a larger, more inchoate group. This effect is only intensified when the transaction costs of identifying and resisting the change are high. ${ }^{110}$

As part of this "environmentalism" to protect the "intellectual" environment, we must first define exactly what we are protecting, which is where the works of Reichman, Rose, and Boyle are very helpful. If we fail to begin this project now, in fifty years we may find ourselves looking back as we consider how the true "tragedy of the commons" was the massive privatization

109. Boyle, supra note 5, at 87.

110. Id. at 110 . 
of the intellectual public domain in the late twentieth century. ${ }^{11}$

\section{THE LEGITIMACY OF CULTURAL APPROPRIATIONS}

Connected to questions about our legal construction of the intellectual public domain are additional and troubling questions of cross-cultural appropriations that occur with greater frequency in the not-so-brave new world economic order of TRIPS and globalization. We need to be careful about constructing the public domain to avoid conceiving of the biological and cultural resources of the Third World as belonging to the "common heritage of humanity," thereby effectively putting them up for grabs by entrepreneurs from the developed countries eager to turn such public domain items into private intellectual property. There is a paradoxical need to simultaneously rein in the maximalist impulse in the intellectual laws of the developed countries and to imagine ways to protect the cultural and biological resources of the developing and least developed countries. In particular, there is a very serious question whether the category "property," or the historically contingent and individualistic notion of "property" that has arisen in the West, is even appropriate when discussing things like agricultural practices, cell lines, seed plasm, and oral narratives that "belong" to communities rather than individuals. ${ }^{112}$ If we are not capable of acknowledging the existence of different life-worlds and ways of envisioning human beings' relationship to the natural world in our intellectual property laws, then unfortunately, it may be late in the day for biodiversity and hopes for a genuinely multicultural world. ${ }^{13}$

111. See James Boyle, Sold Out, N.Y. Times, Mar. 31, 1996, available in 1996 WL 7499914.

112. See Gana, The Myth of Development, supra note 21; See also Has Creativity Died in the Third World?, supra note 21.

113. For an example of this tendency to conceive of the cultures, indeed, the very bodies of indigenous peoples as "treasure," see Lisa Belkin, Chasing Bad Genes to the Ends of the Earth: The High-Tech Future of Medicine Is Encrypted in the Blood of Remote Peoples. For the New, Intrepid Gene Hunters, There Is Treasure Buried in Those Veins, N.Y. TMMEs MAG., Apr. 26, 1998, at 46, 52 (describing medical expeditions from U.S. Universities to gather genetic materials and blood from peoples in Saudi Arabia (searching for glaucoma gene), Nigeria, Ghana (searching for diabetes gene), Mongolia (searching for deafness gene)), Tristan da Cunha (searching for asthma gene) and the island of Cebu in the Phillipines (searching for cleft palate and lip gene):

There is money to be made in genetic research, because pharmaceutical companies are eager to buy the patent rights for cloned genes that could be used to create new families of drugs. For example, the gene that regulates the production of leptin, which in turn regulates the metabolism of fat, was purchased by the pharmaceutical company Amgen from Rockefeller University for \$20 million. The search for the asthma gene of Tristan de Cunha is being financed by Axys Pharmaceuticals. 
Vandana Shiva, ${ }^{114}$ Ruth L. Gana (Okediji), ${ }^{115}$ Rosemary Coombe, ${ }^{116} \mathrm{James}$ Boyle, ${ }^{117}$ Jack Kloppenberg, ${ }^{118}$ and others ${ }^{119}$ have been writing and working to theorize and publicize what has been called the "Great Seed Ripoff"-international conventions granting "plant breeder's rights allowing commercial plant breeders to use traditional indigenous varieties of seeds, and 'improve' them via minor genetic alterations and then receive patents in the varieties, eventually selling them back to the communities that produced them initially." ${ }^{20}$ However, their concerns go much further than merely protesting the granting of U.S. patents in seed plasm and biologically-engineered genetic material. Vandana Shiva writes:

The freedom that transnational corporations are claiming through intellectual property rights protection in the GATT agreement on Trade Related Intellectual Property Rights is the freedom that European colonizers have claimed since 1492. Columbus set a precedent when he treated the license to conquer non-European peoples as a natural right of European men. The land titles issued by the pope through European kings and queens were the first patents. ... Eurocentric notions of property and piracy are the bases on which the IPR

Id. at 52. See also Naomi Roht-Arriaza, Of Seeds and Shamans: The Appropriation of the Scientific and Technical Knowledge of Indigenous and Local Communities, 17 MiCH. J. INT'L L. 919 (1996).

114. BIOPIRACY, supra note 21.

115. Gana, The Myth of Development, supra note 21.

116. Rosemary J. CoOmbe, Cultural Appropriations: Authorship, Alterity and the LaW (forthcoming 1998).

117. BOYLE, supra note 1.

118. KLOPPENBERG, supra note 21 , at 1492-2000 (1988); JACK R. KLOPPENBERG, JR., SEEDS AND SOVEREIGNTY: The USE AND CONTROL OF PlANT GENETIC RESOURCES (1988).

119. See, e.g., Jeremy Rifkin, The Biotech Century: Human Life as Intellectual Property, NATION, Apr. 13, 1998 at 11; Andrew Kimbrell, Biocolonization: The Patenting of Life and the Global Market in Body Parts, in The CASE AGAINST THE Global ECONOMY, supra note 6; ANDREW KIMBrell, THE HUMAN Body Shop: The ENGINEERING AND MARKETING OF LIFE (1993); Susan Wright, Down on the Animal Pharm: Splicing Away Regulations, NATION, Mar. 11, 1996; Darrell A. Posey, International Agreements and Intellectual Property Right Protection for Indigenous Peoples, in INTELLECTUAL PROPERTY RIGHTS FOR INDIGENOUS PEOPLES: A SOURCEBOOK, supra note 21.

120. See the Plant Variety Protection Act of 1970 that extends patent-like protection to novel varieties of sexually reproduced plants. 7 U.S.C. $\$ \$ 2401-2582$ (1988), amended by the Plant Variety Protection Acts Amendments of 1994, Pub. L. No. 103-349, 108 Stat. 3136. See also 17 U.S.C. $\$ 161$ (1984) (providing for patents in asexually reproduced plants); Craig Edgar, Patenting Nature: GATT on a Hot Tin Roof, 34 WAShbURn L.J. 76 (1994); Shayana Kadidal, Note, Plants, Poverty, and Pharmaceutical Patents, 103 Y ALE L.J. 223 (1993); Erin B. Newman, Earth's Vanishing Medicine Cabinet: Rain Forest Destruction and its Impact on the Pharmaceutical Industry, 20 AM. J.L. \& MED. 479 (1994). 
laws of the GATT and [WTO] have been framed. When Europeans first colonized the non-European world, they felt it was their duty to "discover and conquer," to "subdue, occupy, and possess," ... [e]verything, every society, every culture. The colonies have now been extended to the interior spaces, the "genetic codes" of life-forms from microbes and plants to animals, including humans. . . . The assumption of empty lands, terra nullius, is now being expanded to 'empty life,' seeds and medicinal plants ... [and this] same logic is being used to appropriate biodiversity from the original owners and innovators by defining their seeds, medicinal plants, and medical knowledge as nature, as nonscience, and treating tools of genetic engineering as the yardstick of "improvement.". . At the heart of the GATT treaty and its patent laws is the treatment of biopiracy as a natural right of Western corporations, necessary for the "development" of Third World communities. ${ }^{121}$

The question of the direction of the flow of valuable resources, whether genetic or indigenous agricultural or medical knowledge, is extremely relevant to constructing the intellectual public domain as well. As Vandana Shiva points out, representing the cultural property of non-European peoples as "natural" or "primitive" equates such properties as "unowned" and up for grabs by erstwhile and entrepreneurial "civilized" proprietors. Any formulation of the intellectual public domain must take account of the culture-bound nature of our concepts of property and how:

The model on which protection of creative labor currently [advocated by TRIPS] is premised on a unique combination of convictions about what constitutes property, the role of property, and the use of property rights to allocate resources ... [and] reflect[s] values of liberty, individualism, and autonomy, which are central to the society of western

121. BIOPIRACY, supra note 21, at 2-5. See also Mark Ritchie, et al., Intellectual Property Rights and Biodiversity: The Industrialization of Natural Resources and Traditional Knowledge, $11 \mathrm{ST}$. JOHN's J. LEgAl COMment. 431 (1996); Ajay K. Sharma, The Global Loss of Biodiversity: A Perspective in the Context of the Controversy Over Intellectual Property Rights, 4 U. BALT. INTELL. PROP. L.J. 1 (1995). 
liberalism. ... [This ignores the interests of] developing countries all over the world ... [in] retain[ing] those values that are core to their identities and that ultimately determine how development occurs.... Simply enacting [western-style] intellectual property laws in a cultural, economic and political vacuum is shortsighted and futile. . . Trivial[izing] the contributions of pre-industrial peoples to the wealth of the world's resources in inventions, literature, music, and the arts, despite the fact that some of this contribution continues to supply the industrialized world with answers to modern plagues. ${ }^{122}$

The sad irony is that the intellectual property-rich nations of the developed world have pushed for swift enactment of TRIPS in order to avoid what they claim are disastrous and ruinous levels of piracy of their intellectual properties, whether computer programs, videos, music CDs, movies, or technology, by countries of the developing and least developed nations. However, the ideological content of these piracy claims becomes evident when considering that the fears seem to mask the amount of piracy occurring in the opposite direction-invaluable biological and cultural resources flowing out of the countries of the South as "raw materials" into the developed nations of the North where they are magically transformed in the laboratories of pharmaceutical and agricultural corporations into protected intellectual properties whose value is underwritten by provisions of multilateral agreements such as TRIPS. Vandana Shiva writes:

The United States has accused the Third World of piracy. The estimates for royalties lost are $\$ 202$ million per year for agricultural chemicals and $\$ 2.5$ billion annually for pharmaceuticals. In a 1986 U.S. Department of Commerce survey, U.S. Companies claimed they lost $\$ 23.8$ billion yearly

122. Gana, The Myth of Development, supra note 21, at 339, 341. See also Michael J. Huft, Indigenous Peoples and Drug Discovery Research: A Question of Intellectual Property Rights, 89 NW. U. L. REV. 1678 (1995); Kirstin Peterson, Recent Intellectual Property Trends in Developing Countries, 33 HARV. INT'L L.J. 277 (1992); Vandana Date, Comment, Global "Development" and its Environmental Ramifications-The Interlinking of Ecologically Sustainable Development and Intellectual Property Rights, 27 Golden Gate U. L. REV. 631 (1997); Curtis M. Horton, Protecting Biodiversity and Cultural Diversity Under Intellectual Property Law: Toward a New International System, 10 J. ENVTL L. \& LTTG. 1 (1995). 
due to inadequate or ineffective protection of intellectual property.... [However] if the contributions of Third World peasants and tribespeople are taken into account, the roles are dramatically reversed: the United States would owe Third World countries $\$ 302$ million in agriculture royalties and $\$ 5.1$ billion for pharmaceuticals. ${ }^{123}$

For example, it raises the issue of what role national sovereignty may play in establishing local regimes not only of intellectual property protection, but also local regimes that dictate that certain subject matter will not be susceptible to privatization and appropriation. It may be that despite many rumors of its impending demise in the era of globalization, news of the demise of the nationstate may be premature. Ironically, the increasing transnational proprietors of vast (and private) intellectual property holdings must turn to the national legal regimes in order to underwrite the value of their holdings. Additionally, there is a paradox, because as "free trade" ideally envisages a single global market, traditionally both publishers asserting copyrights and corporations asserting patents have depended on their ability to restrict territorially rights in separate national markets-markets that are underwritten and demarcated by national sovereignty. Thus, it is far from clear that a global intellectual property will be able to be completely free from the centripetal pull of national or local intellectual property regimes.

For example, the Indian Government is currently considering legislation creating a National Bioresource Authority (NBA) to protect India's bioresources and would:

[Prohibit non-Indians] from "obtaining any biological resources for research or commercial utilization or collecting

123. BIOPIRACY, supra note 21 , at 56. See generally Craig D. Jacoby \& Charles Weiss, Recognizing Property Rights in Traditional Biocultural Contribution, 16 STAN. ENVTL. L.J. 74 (1997); Lester I. Yano, Protection of the Ethnobiological Knowledge of Indigenous Peoples, 41 UCLA L. REV. 443 (1993); Ileana Dominguez-Uiban, Harmonization in the Regulation of Phamaceutical Research and Human Rights: The Need to Think Globally, 30 CORNELL INT'L L.J. 245 (1997); John R. Adair, Comment, The Bioprospecting Question: Should the United States Charge Biotechnology Companiesfor the Commercial Use of Public Wild Genetic Resources?, 24 ECOLOGY L.Q. 131 (1997); Robert Weissman, A Long. Strange TRIPS: The Pharmaceutical Industry Drive to Harmonize Global Intellectual Property Rules, and the Remaining WTO Legal Alternatives Available to Third World Countries, 17 U. PA. J. INT'L ECON. L. 1069 (1996); Edgar J. Asebey and Jill D. Kempenaar, Biodiversity Prospecting: Fulfilling the Mandate of the Biodiversity Convention, 28 VAND. J. TRANSNAT'L L. 703 (1995). 
samples or undertaking any activity in the nature of bioprospecting without previous approval of the NBA" [and makes it illegal for an Indian citizen to transfer] "the results of any research with respect to any biological resource for monetary consideration to any person who is not a citizen of India without NBA approval." Violators will face a five-year jail term and a fine of US $\$ 30,000 .{ }^{124}$

This type of legislation has been inspired in large part by the activities of companies such as W.R. Grace, the Native Plant Institute, and the Japanese Terumo Corporation that together have patented a number of products derived from the neem tree. The neem tree is a versatile Indian plant, an evergreen that grows up to fifty feet in height. The neem tree's bark, flowers, seeds, and fruit have been used medicinally since ancient times to treat a wide variety of ailments. Additionally, branches of the neem tree have been used as an antiseptic toothbrush, and its oil has been used in toothpaste and soap. Importantly, residue of neem seeds, after oil has been extracted, has been used for generations as a potent insecticide against locusts, nematodes, mosquito larvae, boll weevils, and beetles. ${ }^{125}$ In 1971, Robert Larson, a U.S. national who was aware of the multiple uses of the neem tree in India, imported neem seeds to the United States and began experimenting with them, ultimately producing and patenting a pesticide named Margosan-O made from neem extract. Since the mid-1980s, Grace and other firms have received over a dozen patents on neem-based solutions and emulsions; Larson sold his patent to W.R. Grace in 1988. W.R. Grace has set up a plant and network to process twenty tons of neem seed per day. Neem seed prices have gone up from 300 rupees per

124. K.S. Jayaraman, India Drafts Law to Protect Bioresources, NATURE, Nov. 13, 1997, at 108. A key provision of the legislation is that no one will be able to apply for a patent based on research or information gathered from any Indian biological resource without informing the NBA. Before giving permission for patenting, the authority will impose a benefit-sharing fee or royalty which will be credited to a biological diversity fund to be used to develop the communities which helped to conserve the biological resources.

See also Sarah Laird, Natural Products and the Commercialization of Traditional Knowledge, in INTELLECTUAL PROPERTY RightS AND INDIGENOUS PEOPLES: A SOURCEBOOK, supra note 21; Stephen B. Brush, A Non-Market Approach to Protecting Biological Resources, in INTELLECTUAL PROPERTY RIGHTS AND INDIGENOUS PEOPLES: A SOURCEBOOK 131, supra note 21; Compare R. King, Establishing Reciprociry: Biodiversity, Conservation and New Models for Cooperation Between Forest-Dwelling Peoples and the Pharmaceutical Industry, in INTELLECTUAL PROPERTY RIGHTS AND INDIGENOUS PEOPLES: A SOURCEBOOK 69, supra note 21.

125. Vandana Shiva \& Radha Holla-Bhar, Piracy by Patent: The Case of the Neem Tree, in THE CASE AGAINST THE GLOBAL ECONOMY, supra note 6, at 146. 
ton to 3000 to 4000 rupees per ton, turning:

\begin{abstract}
[A]n often free resource into an exorbitantly priced one, with the local user now competing for seed with an industry that is supplying wealthy consumers in the North. As the local farmer cannot afford the price that industry can, the diversion of the seed as raw material from the community to industry will ultimately establish a regime in which a handful of companies holding patents will control all access and all production related to neem as raw material. ${ }^{126}$
\end{abstract}

Another example of this biocolonialism where resources and discoveries flow out of the Third World as "raw materials," only to return from the laboratories of the West as intellectual properties owned by foreign corporations, is the case of the African Soapberry. The African Soapberry has been used traditionally for centuries as insecticide and fish intoxicant. In 1964 an Ethiopian researcher, Dr. Akilu Lemma, reported to the English Tropical Products Institute that the African Soapberry of Endod was toxic to watersnails that carried the disease dilharzia. Subsequently, the Tropical Plant Institute patented an extraction process to produce a commercial molluscicide to kill zebra mussels that clog North American waterways. Dr. Lemma was neither credited for the discovery nor receives any royalties. ${ }^{127}$

Even human beings are not exempt from this process. National sovereignty cuts both ways. While India or the countries of the European Union may not want to go down the path of biopatents, the United States has forged ahead full speed. Since the landmark 1980 U.S. Supreme Court case, Diamond $v$. Chakrabarty, ${ }^{128}$ that upheld Dr. Ananda K. Chakrabarty's (a General Electric microbiologist) patent claim in a genetically engineered oil-eating bacteria, the holding thereby overturned the traditional legal rule that "products of nature" such as life-forms were not patentable subject matter. In 1985, the U.S. Patent and Trade Office (PTO) granted a patent to Dr. Kenneth Hibberd on the

126. Id. at 153; See also Shayana Kadidal, Subject-Matter Imperialism? Biodiversity, Foreign Prior Art and the Neem Patent Controversy, 37 IDEA 371 (1997).

127. Shiva \& Holla-Bhar, supra note 125 , at 155 . See also the patent granted to RiceTec for genetically engineered Basmati Rice (U.S. Patent No. 5,663,484 (Sept. 2, 1997)) that was protested by over 50,000 people at the U.S. Embassy in New Delhi, India, in May 1998; See generally Statement from Peoples' Movements \& NGOs in Southeast Asia to the World Trade Organization, No Patents on Rice! No Patents on Life! (May 15, 1998) (on file with the Indiana Journal of Global Legal Studies).

128. Diamond v. Chakrabarty, 447 U.S. 303 (1980). 
culture, seed, and plant of an entire line of corn. ${ }^{129}$ In 1987, the PTO granted a patent to Philip Leder and Timothy Stewart on a genetically engineered mouse. ${ }^{130}$ If carried to its logical extreme, the question arises that if a genetically engineered mouse could be patented, why not a genetically engineered person (or part of a person)?

For years epidemiologists have noted that a virus associated with hairy-cell leukemia was prevalent among the Guayami tribe in Panama. In the early 1990s, U.S. researchers took blood samples from members of the Guayami tribe to analyze. In particular, the blood of a twenty-six year old mother of two who had contracted hairy-cell leukemia interested the researchers. In December 1991, acting on the behest of the U.S. Commerce Department, the researchers applied for a patent on a cultivated cell line from the Guayami woman's blood. The patent application listed Dr. Jonathan Kaplan of the Centers for Disease Control in Atlanta as the "inventor" of the cell line. ${ }^{131}$

Opposition to the global politics of intellectual property is emerging. For example, in March 1995, the European Parliament voted to ban the patenting of life-forms. When news of the patent application for the Guayami woman's cell line reached the press, religious leaders and indigenous communities were outraged, and the Commerce Department eventually abandoned its patent application in November 1993. In October 1993, on Gandhi's birthday, 500,000 Indian farmers staged a mass protest in Bangladore at the Indian offices of Cargill Seeds Private Ltd., a subsidiary of the largest privately held corporation in the United States. The farmers objected to the patenting of the neem seed which had been used in their farming communities for centuries-as well as the agricultural and intellectual property provisions of the then imminent GATT. ${ }^{132}$

129. See Ex parte Hibberd, 227 U.S.P.Q. (BNA) 443 (Bd. Pat. App. \& Interf. 1985).

130. See U.S. Patent No. 4,736,866 (April 12, 1988); Keith Schneider, Harvard Gets Mouse Patent, A World First, N.Y. TIMES, Apr. 13, 1988, at A1.

131. Kimbrell, Biocolonization, supra note 119 , at 142-43. On the possibility of someone (or a corporation) becoming the Bill Gates or Microsoft of the Human Genome, see Nicholas Wade, Scientist's Plan: Map All DNA Within 3 Years, N.Y. TIMES, May 10, 1998, at Al:

Perkins-Elmer intends to be sparring in laying claim to intellectual property rights over the genome, believing the company will create more demand for its [gene-sequencing] machines if it allows its sequences to be widely accessible. . . Whether the new company could gain a significant lock on the human genomes ... is not at all clear. Human Genome Sciences [another biotech company], for example, has already obtained the full-length sequence of 80 percent of human genes . . . and has presumably filed patent applications.

132. Philip L. Bereano, Patent Nonsense - Patent Pending: The Race to Own DNA, SEATtLe TimeS, Aug. 27, 1995, at B5. 
These trends also hold ominous prospects within countries such as the United States. In March 1998, using about $\$ 229,000$ of government funds, the U.S. Department of Agriculture (USDA), in collaboration with Delta and Pine Land Company (the largest producer of cotton seeds with a seventy-three percent market share), received a patent for a genetic "technology protection system"133 that makes it possible for seed companies to sell seeds that will work only for a single growing season. Crops will grow, but their seeds will be unable to germinate. This marks a radical break with farming traditions worldwide-the practice of farmers saving seeds from one growing season to the next.

In South America, poor farmers use knowledge passed down over centuries to select seeds best suited to the local climate and soil. Across the equator their counterparts in South Dakota do it too; 80 to 90 percent of wheat farmers there save seeds from harvest. ... Seed saving may be good for farmers, but it's not good for the chemical and seed companies who are spending billions to develop genetically engineered seed varieties. Although a 1970 law permits U.S. farmers to save proprietary seeds for use on their own farms, companies selling genetically engineered varieties now say that farmers must not reuse their patented varieties at all. They say they can't make ends meet unless farmers pay each and every season.

Biotech seed companies have managed to control the "problem" of seed saving in this country by policing farmers. ... How can these companies continue spending millions to develop new high-tech seeds if they can't reach the millions of farmers in the untapped markets of China, India, Pakistan, South America?

USDA to the rescue. "The need was there to come up with a system that allowed you to self-police your technology, other than trying to put on laws and legal barriers to farmers saving

133. See U.S. Patent No. 5,723,765 (Mar. 3, 1998) (for Control of Plant Gene Expression; Assignee: Delta and Pine Land Co. and the United States Department of Agriculture). 
seed, and to try and stop foreign interests from stealing the technology," says USDA Scientist Melvin Oliver, the primary inventor of the new patent-protecting technology. Oliver says the invention is a way to "put billions of dollars spent on research back into the system."

Oliver's "invention" covers both transgenic and ordinary varieties of seeds and could even be applied to self-pollinating varieties of wheat, oat, and rice. With this technology, farmers growing those varieties would have to buy new seed every year. Monsanto, Pioneer, Hi-Bred, and Novartis, and other seed companies have already taken licenses on the "Terminator" technology-licensing revenue is expected to be approximately two million dollars a year to the USDA and Delta and Pine. In May 1998, Monsanto acquired control of Delta and Pine. This technology may be seen as:

A threat to millions of resource-poor farmers who depend on saving seeds, and exchanging seed with their neighbors, for their livelihood. . . . Since the technology will enable multinational seed companies to enter Second and Third World markets, there is also the fear that greater amounts of identical crops will be grown worldwide, increasing monocropping and further eroding agricultural biodiversity. ${ }^{135}$

134. Leora Broydo, A Seedy Business: A New "Terminator" Technology Will Make Crops Sterile and Force Farmers to Buy Seeds More Often-So Why Did the U.S.D.A. Invent It?, MOTHER JONES ONLNE, (Apr. 7, 1998) at <http://www.mojones.com/news_wire/broydo.html>.

135. Id.; interestingly, Monsanto Co. announced in May 1998 that it bought DeKalb Genetics Corp. for $\$ 2.3$ billion and Delta \& Pine Land Co. (and presumably the Terminator patent) for \$1.9 billion. See Scott Kilman, Monsanto Buys Two Companies for $\$ 4.2$ Billion, WALL ST. J., May 12, 1998, at A2:

Though expensive, the acquisitions would give Monsanto an army that rivals the muscle of the biotechnology alliance formed last year between DuPont Co. and pioneer Hi-Bred International Inc. . . The upshot is that some of the most important types of crop technology are dominated by two companies: Monsanto and DuPont, a Wilimington, Del., Chemicals giant. . . . The huge premiums paid by Monsanto reflect the intense race by the globe's chemical giants to build businesses that can exploit their expanding knowledge about genetic engineering of plants. . . DeKalb Genetics was the last big U.S. seed company available for purchase; it controls $11 \%$ of the lucrative North American corn-seed market [holding a patent] for genetically engineering a com plant to make an insecticide that is harmless to humans. U.S. farmers are planting about 12 million acres with the seed this spring.

See also Scott Kilman \& Susan Warren, Old Rivals Fight for New Turf-Biotech Crops, WALL St. J., May 27, 1998, at B1:

In the three years since the first transgenic seeds were introduced, crop biotechnology 
In another related example, Monsanto, a multinational agrochemical corporation based in the United States, recently genetically engineered and patented soybean and cotton seeds amenable to direct applications of another patented Monsanto product, a broad-spectrum herbicide, ROUNDUP. These seeds are called ROUNDUP READY, but they have an additional characteristic: crops will die if they are sprayed with broad-spectrum herbicides manufactured by other companies. ${ }^{136}$ Other agrochemical multinational corporations are getting into the act as well. Plant patents have been granted to varieties of crop plants that are resistant to Ciba-Geigy's ATRAZINE herbicide and DuPont's GIST and GLEAN-it is easier (and cheaper) via genetic engineering to make the crop fit the chemical herbicide or pesticide than vice versa. A new crop variety may cost two million dollars to develop and patent, but a new herbicide may cost more than forty million dollars. ${ }^{137}$

Monsanto's ROUNDUP READY cotton comprises about three million acres of the fourteen million acres of U.S. cotton crop. Use of a Monsanto brand cotton guarantees use of a Monsanto-brand herbicide-good for corporate profits, but not so good for genomic crop diversity. In the summer of 1997, the three million acres of Monsanto-brand suffered a catastrophic crop

has grown from a young science to a hot business: About half of U.S. cotton fields, $40 \%$ of soybean fields and $20 \%$ of corn fields are genetically altered. Now, in a stunningly swift concentration of power, much of the design, harvest and processing of genetically engineered crops is coming under [Monsanto and DuPont's] influence. . . . Monsanto alone stands to control a staggering $80 \%$ of the U.S. cotton-seed market, if pending transactions win regulatory approval. . . Seeds equipped with Monsanto genes are being planted around the globe this year on roughly 55 million acres-roughly the size of all the farmland in lowa and Illinois. But DuPont has more patents for the [next] and potentially far more valuable - wave, which involves changing plants' nutritional attributes ... [such as] instructing soybeans to make more of a natural compound that might fight cancer, or making corn that reduces the amount of saturated fat in the eggs of the chickens that eat it. . . . Monsanto [has formed] a joint venture with the grainprocessing behemoth Cargill Inc. ... [ [which is] America's biggest closely held company, with fiscal 1997 sales of $\$ 56$ billion. . . The shrinking number of independent seed companies is making U.S. farm organizations nervous, and public interest groups are complaining to the Clinton administration officials. Monsanto and DuPont "have a choke hold on germ plasm," or the reproductive cells in plants, says Margaret Mellon of the Union of Concemed Scientists, an activist group.

136. See Mark Arax, No Way Around Roundup: Monsanto's Bioengineered Seeds Are Designed to Require More of the Company's Herbicide, MOTHER JONES, (Jan.-Feb. 1997), <http://bsd.mojones.com/mother_jones/JF97/brokaw.html>; Robert Steyer, Monsanto Gets Green Light on Altered Soybeans, ST. LouIS Post-DiSPATCH, May 26, 1995, at 13D; See generally Karen Lehman \& Al Krebs, Control of the World's Food Supply, in THE CASE AGANST THE GLOBAL ECONOMY, supra note 6, at 122.

137. Vandana Shiva, Monocultures of THE MiND, PERSPEctives ON BIOdIVERSTTY AND BIOTECHNOLOGY 112 (1993). 
failure. The cause of the failure was unclear. Monsanto also sells a genetically engineered variety of cotton called BOLLGARD that was bioengineered with Bacillus thurengesis DNA to produce proteins that were toxic to the bollworm; however, BOLLGARD cotton ended up having twenty to fifty times the normal level of bollworm infestation. However, to the extent that the use of patented seed stock such as ROUNDUP READY or BOLLGARD become widespread, farmers who use such stock must sign restrictive licensing agreements wherein they agree to terms such as allowing Monsanto to inspect their fields, to use only Monsanto-brand herbicides and not to save seed for further planting-all of which contribute to both further centralization of agribusiness and increasing as well as potentially disastrous dependence on vulnerable monocultured seed stock (ten seed companies control about forty percent of the commercial seed market ${ }^{138}$ )—results that some have referred to as "bioserfdom" underwritten by our intellectual property laws. ${ }^{139}$

\section{CONCLUSION}

This Article has briefly raised questions about the emerging globalized vision of intellectual property protection embedded in multilateral agreements such as the TRIPS component of GATT. In particular, there are serious distributive questions about the international political economy of intellectual property protection as between the "have" and "have-not" nations that should be addressed sooner rather than later. Additionally, on both national and international levels, the question of constructing and maintaining an intellectual public domain or commons remains extremely important, if only because the unprecedented grab by intellectual property owners of the developed nations of the North seems to be imminent. This grabbing obscures traditional understanding (at least within the Anglo-American intellectual property tradition) that intellectual property law is about striking a vital and important balance between the rights of authors and inventors and the public of consumers and users as well as the fact that all intellectual property owners are also users.

Finally, and perhaps most disturbingly, what are we to make of the massive and generally uncompensated flow of cultural and biological resources out of

138. Broydo, supra note 134 , at 56. at $\mathrm{A} 24$.

139. See Verlyn Klinkenborg, Biotechnology and the Future of Agriculture, N.Y. TIMES, Dec. 8, 1997, 
the developing and least developed nations of the South (where they are characterized as "raw materials" or "naturally occurring") into the laboratories, universities, and factories of the developed nations of the North and emerge as strongly-protected and economically valuable intellectual properties, protected against "pirates" of the developing nations by multilateral intellectual property agreements? At the very least, it is becoming increasingly clear that, whether on the domestic or international level, the vicious circle of increasingly strong (and virtually automatic) intellectual property protection comes with some serious costs on both the local and global levels and deserves to be addressed now. 